Discussion Paper No. 10-027

Temporary Extra Jobs for Immigrants: Merging Lane to Employment or Dead-End Road in Welfare?

Stephan L. Thomsen and Thomas Walter

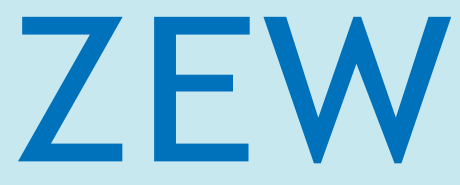

Zentrum für Europäische Wirtschaftsforschung $\mathrm{GmbH}$

Centre for European

Economic Research 
Discussion Paper No. 10-027

\section{Temporary Extra Jobs for Immigrants: Merging Lane to Employment or Dead-End Road in Welfare?}

Stephan L. Thomsen and Thomas Walter

Download this ZEW Discussion Paper from our ftp server:

ftp://ftp.zew.de/pub/zew-docs/dp/dp10027.pdf

Die Discussion Papers dienen einer möglichst schnellen Verbreitung von neueren Forschungsarbeiten des ZEW. Die Beiträge liegen in alleiniger Verantwortung der Autoren und stellen nicht notwendigerweise die Meinung des ZEW dar.

Discussion Papers are intended to make results of ZEW research promptly available to other economists in order to encourage discussion and suggestions for revisions. The authors are solely responsible for the contents which do not necessarily represent the opinion of the ZEW. 


\section{Non-technical summary}

In the context of a substantial welfare reform in 2005, a new employment program has been introduced in Germany, the so-called Temporary Extra Jobs. These jobs provide temporary work opportunities in the public sector for welfare recipients in order to maintain or enhance the employability of the participants and to improve the job chances for regular employment. While engaged, participants receive welfare benefits, and, in addition, for their efforts in the program, they are paid an hourly wage of between 1 and 2 Euro. Occupations in Temporary Extra Jobs have to be additional in nature, of value for society, and must not compete with regular jobs in the market. Despite being intended to act as a last resort of activation for the most disadvantaged welfare recipients, this function is hardly met. With more than 750,000 participants each year, the program is the most frequently used welfare-towork program in Germany.

Within the population of welfare recipients in Germany, immigrants are clearly over-represented with a two thirds larger share than in the overall population. In 2006, more than 34 percent of all welfare recipients were immigrants while their corresponding share of the population was only about 19.5 percent. However, despite their over-representation in welfare, immigrants are not a specific priority group. For this reason, German welfare lacks integration plans for immigrants that are offered in other countries. Instead, immigrants are placed in the standard welfare-to-work programs that have been designed for all welfare recipients. Therefore, immigrants are also frequently placed in Temporary Extra Jobs, even though the use of the program in this group is somewhat less pronounced than in the group of native Germans.

In this paper, we evaluate the effects of participating in a Temporary Extra Job on the chance of exiting welfare by taking up employment for immigrant welfare recipients. Since Germany's welfare-towork programs are not particularly designed for immigrants but for all welfare recipients, we contrast the findings to the effects for native Germans. In addition, we analyze potential differences in the effects between the two ethnic groups trying to illuminate the causes of these differences. For the empirical analysis we use an inflow sample into welfare in 2006 of about 160,000 observations with individual information obtained from register data. These data enable quite a detailed characterization of the labor market past and current situation of immigrants and natives by covering comprehensive information. In addition, they enable identification of immigrants beyond the concept of citizenship.

Our results show, that instead of increasing employment chances Temporary Extra Jobs rather reduce the probability of participants to take up a regular job providing a sufficient income above the subsistence level. Treatment effects are especially adverse if a Temporary Extra Job is started during the second quarter of a welfare spell. Even though program effects for immigrants are in many cases not as unfavorable as for natives, Temporary Extra Jobs are not an effective activation measure for this group either. The analysis of the differences in treatment effects shows that immigrants benefit more from Temporary Extra Jobs than natives with otherwise identical characteristics. However, using this result to derive the conclusion that Temporary Extra Jobs should be more frequently used for immigrants is misleading. The strong negative treatment effects Temporary Extra Jobs exhibit for both ethnic groups indicate that the program fails to achieve its objectives. The effects are more adverse for natives, but the program does not help immigrants either to leave the welfare system. Temporary Extra Jobs are a dead-end road in welfare rather than a merging lane to regular employment both for immigrants and for natives. 


\section{Das Wichtigste in Kürze}

Im Zuge der sogenannten Hartz IV-Reform im Jahr 2005 wurde mit den Arbeitsgelegenheiten in der Mehraufwandsvariante ein neues arbeitsmarktpolitisches Instrument zur Aktivierung von erwerbsfähigen Hilfebedürftigen geschaffen. Die Arbeitsgelegenheiten sind geförderte, in der Regel sechs Monate andauernde Beschäftigungsverhältnisse im öffentlichen Sektor, die zusätzlich, wettbewerbsneutral und arbeitsmarktpolitisch zweckmäßig sein sollen. Ziel der Förderung ist es, die Beschäftigungsfähigkeit der Teilnehmer zu erhalten bzw. zu verbessern und somit die Chancen auf den Übergang in eine reguläre Beschäftigung zu erhöhen. Während der Teilnahme erhalten die Hilfebedürftigen weiterhin Arbeitslosengeld II und zudem eine Mehraufwandsentschädigung in Höhe von etwa 1 bis 2 Euro pro Arbeitsstunde, daher werden Arbeitsgelegenheiten in der Mehraufwandsvariante auch als Ein-EuroJobs oder Zusatzjobs bezeichnet. Nach Intention des Gesetzgebers sollen insbesondere benachteiligte Hilfebedürftige gefördert werden, die besondere Schwierigkeiten haben, eine Beschäftigung zu finden. In der Praxis lässt sich eine solche Ausrichtung der Förderung auf benachteiligte Personen allerdings nicht feststellen; mit mehr als 750.000 Teilnehmern pro Jahr sind Ein-Euro-Jobs das am häufigsten eingesetzte Aktivierungsinstrument im Rechtskreis des SGB II.

Der Anteil von Immigranten im Rechtskreis des SGB II ist stark überproportional. So hatten in Deutschland im Jahr 2006 mehr als 34 Prozent aller erwerbsfähigen Hilfebedürftigen einen Migrationshintergrund, wohingegen der Anteil in der gesamten Bevölkerung lediglich 19,5 Prozent betrug. Trotz dieser starken Betroffenheit von Hilfebedürftigkeit stellen Personen mit Migrationshintergrund keine spezielle Zielgruppe des SGB II dar. Im Unterschied zu vielen anderen Ländern der OECD existieren keine spezifisch auf die Eigenschaften und Bedürfnisse von Immigranten abgestimmte Aktivierungsinstrumente. Vielmehr werden Immigranten mit den gleichen Maßnahmen gefördert, die auch für Personen ohne Migrationshintergrund eingesetzt werden. Immigranten werden daher auch häufig in Ein-Euro-Jobs vermittelt, wenn auch in etwas geringerem Ausmaße als Einheimische.

In dieser Studie untersuchen wir die Beschäftigungswirkungen von Ein-Euro-Jobs für Personen mit Migrationshintergrund und vergleichen diese mit den Maßnahmeeffekten für Personen ohne Migrationshintergrund. Zudem analysieren wir die Gründe für einen möglichen Unterschied in der Effektivität der Maßnahme zwischen beiden Gruppen. Dabei verwenden wir Geschäftsdaten der Bundesagentur für Arbeit mit umfangreichen Informationen zu 160.000 Personen, die im Jahr 2006 in den Rechtskreis des SGB II zugegangen sind. Diese Daten ermöglichen eine detaillierte Darstellung und Berücksichtigung der Erwerbsbiographie der betrachteten Personen. Zudem erlauben sie eine Identifikation von Personen mit Migrationshintergrund über die bloße Information der Staatsbürgerschaft hinaus.

Unsere Ergebnisse zeigen, dass Ein-Euro-Jobs ihre intendierten Wirkungen nicht erreichen. Anstatt die Beschäftigungschancen zu erhöhen, verringern sie die Wahrscheinlichkeit, dass Teilnehmer eine reguläre Beschäftigung finden und aus dem Arbeitslosengeld II-Bezug abgehen. Die Maßnahmeeffekte sind insbesondere dann negativ, wenn die Zuweisung in einen Ein-Euro-Job während des zweiten Quartals nach dem Zugang in den Rechtskreis des SGB II erfolgt. Auch wenn die ermittelten Effekte für Immigranten häufig etwas günstiger ausfallen als für Personen ohne Migrationshintergrund, sind Ein-Euro-Jobs auch in dieser Personengruppe kein geeignetes Instrument, um die Hilfebedürftigkeit durch die Aufnahme einer Beschäftigung zu überwinden. Ein-Euro-Jobs führen somit sowohl für Immigranten als auch für Einheimische hinsichtlich der Aufnahme bedarfsdeckender Beschäftigung in eine Sackgasse. 


\title{
TEMPORARY EXTRA JOBS FOR IMMIGRANTS: Merging Lane to Employment or Dead-End Road in WELFARE?*
}

\author{
Stephan L. Thomsen ${ }^{\dagger}$ \\ University of Magdeburg $\&$ ZEW Mannheim \\ Thomas Walter $\ddagger$ \\ ZEW Mannheim
}

This version: April 16, 2010

\begin{abstract}
We evaluate the effects of the most frequently used German welfare-to-work program on the employment chances of immigrant welfare recipients. In particular, we investigate whether program effects differ between immigrants and natives and what might cause these potential differences. Our results reveal that the program fails to achieve its objectives. The effects are more adverse for natives, but the program does not help otherwise identical immigrants to leave the welfare system either. Therefore, the program is a dead-end road rather than a merging lane to regular employment both for natives and for immigrants.
\end{abstract}

Keywords: Immigrants, employment programs, evaluation, decomposition of effects, Germany

JEL Classification: I38, C14, J61

\footnotetext{
${ }^{*}$ Financial support from the project Evaluation of the Effects of Basic Social Care for Job Seekers with Migration Background in Germany commissioned by the Federal Ministry of Labor and Social Affairs (BMAS) is gratefully acknowledged. Stephan L. Thomsen thanks the Stifterverband für die Deutsche Wissenschaft (ClaussenSimon-Stiftung) for financial support.

${ }^{\dagger}$ Stephan L. Thomsen is Assistant Professor of Labor Economics at Otto-von-Guericke-University Magdeburg and Research Associate at ZEW, Mannheim. Address: Otto-von-Guericke-University, Department of Economics and Management, PO Box 4120, D-39016 Magdeburg, e-mail: stephan.thomsen@ovgu.de, phone: +49 391 6718431, fax: +493916711700.

${ }^{\ddagger}$ Thomas Walter (Corresponding author) is Research Assistant at the Centre for European Economic Research (ZEW), Mannheim. Address: L7, 1, D-68161 Mannheim, e-mail: walter@zew.de, phone: +49 621 1235363, fax: +49621 1235225 .
} 


\section{Introduction}

Welfare in Germany provides last resort (financial) support for people in need of assistance who are not eligible to claim unemployment benefits or whose claims are too low. Receiving support, covering welfare benefits and maintenance allowances, requires the claimants to register with the local welfare agency and to actively look for a job. Job search efforts should be supported by the welfare agency and welfare recipients are obliged to participate in welfare-to-work programs if requested. These programs are generally intended for hard-to-place individuals. Within the population of welfare recipients, immigrants are clearly over-represented with a two thirds larger share than in the overall population of Germany. According to Bundesministerium für Arbeit und Soziales (2009), in 2006 more than 34 percent of all welfare recipients were immigrants. As reviewed by OECD (2008), low participation rates, high unemployment rates and high welfare rates characterize immigrants in a number of OECD countries. The larger difficulties of labor market integration of immigrants compared to natives reflect the lower degree of employability. Hence, similar to other countries, immigrant welfare recipients are likely to be placed in welfare-to-work programs. Nevertheless, there exists no specific set of programs designed for the particular needs of the immigrants in Germany. Instead, immigrants are usually assigned to the standard intervention measures.

In the context of a substantial welfare reform in 2005, a new employment program has been introduced in Germany, the so-called Temporary Extra Jobs $^{1}$ offering temporary job opportunities in the public sector for welfare recipients. Jobs comprise a variety of activities, frequently in community services or in public infrastructure. To avoid distortions of competition, jobs must be additional and must not compete with regular employment. Since its introduction, more than 750,000 welfare recipients have been newly employed in Temporary Extra Jobs each year, and, therefore, the program is the most frequently used welfare-to-work program in Germany. The main purpose is to maintain and improve the employability of the participants and to be a means for (later) integration in regular jobs. Put differently, the offered work opportunities should provide a merging lane to permanent employment.

In this paper, we evaluate the effects of working in a Temporary Extra Job on the chances of exiting welfare by taking up employment for immigrant welfare recipients. Since Germany's welfare-to-work programs are not particularly designed for immigrants but for all welfare recipients, we will contrast the findings to the effects for native Germans. In addition, we will analyze potential differences in the effects between the two ethnic groups trying to illuminate

\footnotetext{
${ }^{1}$ In German the program is called Arbeitsgelegenheiten in der Mehraufwandsvariante.
} 
the causes of these differences. For the empirical analysis we use an inflow sample into welfare in 2006 of about 160,000 observations with individual information obtained from register data. These data enable quite a detailed characterization of the labor market past and current situation of natives and immigrants by covering comprehensive information. In addition, they enable identification of immigrants beyond the concept of citizenship. Using a broader definition of immigration than relying on citizenship is sensible in the German context since more than half of the immigrant population possesses German citizenship (see Statistisches Bundesamt, 2006). We apply propensity score matching to estimate average effects of treatment on the treated (ATT) in a dynamic setting, where treatment effects vary conditionally on the preceding duration in welfare. This estimation strategy is adequate to identify the effectiveness of Temporary Extra Jobs with respect to the timing of treatment and has been used in the evaluation of similar programs before. To analyze the causes of potential differences in treatment effects between immigrant and native participants in Temporary Extra Jobs, we follow the approach suggested by Aldashev, Thomsen, and Walter (2010) and decompose the differences in treatment effects based on the matching estimator into differences due to the socio-economic composition of the groups and into differences due to an immigrant fixed effect. The latter captures influences of unobservable factors in the estimation.

Determining the source of differences in program effectiveness between the two ethnic groups is important. If, for example, differences in program effectiveness are driven by differences in the composition of immigrant and native welfare recipients it implies a general potential for welfare agencies to improve the targeting of programs to participants. If, on the other hand, differences are due to the immigrant characteristic, then this points to discrimination in the effectiveness of Temporary Extra Jobs and the question arises whether the use of the program for specific ethnic groups is reasonable at all. Clearly, both possible explanations for differences in program effects must cause concern among policy makers. However, since effect differences due to an immigrant fixed effect per se are especially problematic and affect more than one third of the welfare population, we will mainly focus on the contribution of the immigrant fixed effect to the observed differences in the effectiveness of Temporary Extra Jobs.

In contrast to the US, where welfare research traditionally has played a more prominent role and welfare-to-work programs have been adopted in various states particularly during the 1990s, in European countries welfare-to-work programs have become important more recently only as a result of substantial reforms. ${ }^{2}$ Accordingly, the empirical literature on evaluation of social

\footnotetext{
${ }^{2}$ For comprehensive overviews on the welfare reforms in the US and related empirical studies see, for example, Blank (2002) and Moffit (2002). More information on the recent reforms in European countries is provided, besides others, by Finn (2000) for the UK and the Netherlands, Jacobi and Kluve (2007) for Germany, or
} 
intervention programs in Europe focusses on active labor market programs for unemployed individuals rather than welfare recipients. Reviews of the numerous available studies are provided, for example, by Martin and Grubb (2001), Kluve and Schmidt (2002), or Kluve (2010). Employment programs similar to Temporary Extra Jobs exist in a number of countries and have been used for unemployed persons in Germany as well. Comprehensive evaluations of those programs in Germany, see e.g., Thomsen (2007) and Hujer and Thomsen (2010), report disappointing results with respect to the employment chances of participating individuals. These findings are in line with the international experiences. In his meta-analysis of the effects of European active labor market programs, Kluve (2010) considers the effects of employment programs from various countries. In his category direct employment programs in the public sector he regards activities aimed at direct job creation or public work provision and other activities that produce public goods and services. By and large, he identifies 24 studies evaluating this kind of program. Only 5 of the studies considered find those programs to be effective. 12 studies report clearly negative effects for individuals and another 7 report no effects (insignificant estimates). Thus, the international picture on direct job creation is not very promising with regard to reducing unemployment and increasing employment.

Transferring these findings to the case of welfare recipients and, more specifically, to the large group of immigrant welfare recipients is not directly possible since welfare recipients usually differ from registered unemployed persons with regard to employment chances and further labor market relevant characteristics. Therefore, distinct evaluations are necessary. Moreover, given the large share of immigrants in the welfare system, it is important to know whether Temporary Extra Jobs affect the employment chances of immigrants and natives similarly or whether there are differences between the two ethnic groups and what causes these potential differences.

Temporary Extra Jobs have been analyzed in three former studies; however, these studies suffer in a number of respects. Hohmeyer and Wolff (2007) use a stock sample of welfare recipients from January 2005 who participated in Temporary Extra Jobs from February to April 2005 and who were followed for 20 months after program start. They find insignificant effects on employment uptake for men and slightly positive effects for women. They also distinguish between immigrants and native Germans as sub-groups of their analysis and find a positive employment effect for female immigrants in West Germany at the end of their observation period. ${ }^{3}$ However, several short-comings may cast doubt on the reliability of the estimates. Halverson and Jensen (2004) for the Nordic countries.

${ }^{3}$ Hohmeyer (2009) uses the same data as Hohmeyer and Wolff (2007) but extends the observation period to 28 months and distinguishes between different types of Temporary Extra Jobs according to overall program duration and working hours per week. She finds similar results but does not look at immigrants separately. 
First, the substantial German welfare reform and, thus, Temporary Extra Jobs were introduced only at the beginning of 2005 and implementation took almost the whole year due to a number of problems. In particular, data collection problems occurred from the change which may affect the results. Secondly, relying on a stock sample of welfare recipients may result in biased estimates due to over-representation of long-spells which may be a particularly severe problem in the group of welfare recipients. Although the sample was drawn at the end of the first month of the new system, welfare recipients originated from the former systems of social assistance and unemployment assistance and could have been in the systems for several years already. In addition, the sampling design does not allow to take into account the exact timing of treatment during the welfare spell. Finally, the choice of outcome variables is not ideal. Hohmeyer and Wolff (2007) look at employment uptake irrespective of welfare status, but it remains unclear what can be learned from this variable. A more appropriate outcome would be a combined measure indicating departure from welfare receipt conditional on employment uptake. Only with such a combined measure can the success of the program be assessed since its objective is to reduce welfare dependency by bringing welfare recipients back into employment.

Huber, Lechner, Wunsch, and Walter (2010) use such a combined measure. They evaluate the effects of a set of welfare-to-work programs including Temporary Extra Jobs. Using data on a stock sample of welfare recipients from October 2006 with information on the labor market states until the end of 2007, they find no significant treatment effects for participation in Temporary Extra Jobs on leaving welfare by taking up employment. They also attempt to consider immigrants separately but the sub-sample size becomes very small and no significant effects are obtained either. Based on the comparably informative data for the later time period, the estimated effects should not be troubled from implementation or data collection problems. However, the sampling design and short-observation period of one year for studying programs that last for about six months may hamper conclusive interpretation of the results. The study at hand overcomes the limitations of the former analyses due to the use of an inflow sample of welfare recipients in Germany in 2006 who are followed until July 2007. In addition, we provide evidence on the causes for potential effect differences between immigrant and native participants in Temporary Extra Jobs.

Our empirical results show strong locking-in effects of the program independently of gender and ethnic group during participation. Afterwards, program effects tend to increase only slightly and remain negative or at best insignificant until the end of the observation period in all groups. The negative effects are a bit more pronounced for natives than for immigrants. The results of the decomposition indicate that immigrants who are similar in observable characteristics 
benefit more from Temporary Extra Jobs than natives, i.e. a positive immigrant fixed effect could be established. Nevertheless, despite this finding Temporary Extra Jobs fail to achieve the intended purpose of providing a means for re-employment for welfare recipients.

The remainder of the paper is organized as follows. The next section describes the institutional background of the German welfare system and the set-up and eligibility rules for Temporary Extra Jobs. The data used for the empirical analysis are introduced in section 3. The identification, estimation, and decomposition strategy of treatment effects for immigrants in reference to native Germans is outlined in section 4. Section 5 presents the empirical estimates and their interpretation. The final section concludes. ${ }^{4}$

\section{Institutional Background}

\subsection{The German Welfare System}

The German welfare system was substantially reformed at the beginning of 2005 with the introduction of the new Social Code II (Sozialgesetzbuch II). ${ }^{5}$ Until 2005, persons whose unemployment benefit (UB) claims had expired were eligible for unemployment assistance (UA), which replaced up to $57 \%$ of the previous net earnings. Persons, who had not contributed to unemployment insurance before, were eligible for social assistance (SA). If UA was too low to provide a minimum living standard, a combination of UA and SA was granted. In contrast to UB, UA and SA were both means-tested. With the welfare reform of January 2005, both programs were replaced by the so-called unemployment benefits II scheme (UBII). As opposed to UA, UBII (as former SA) does not depend on former earnings. The means-test takes into account the wealth and income of all individuals living in the household. At the beginning of 2005, UBII benefits for a single individual without children amounted to EUR 345 in West Germany and to EUR 331 in East Germany. Meanwhile, the level of UBII in East Germany was adjusted to the Western level and UBII was slightly raised in both parts to compensate for inflation (359 Euro since July 09). Moreover, UBII welfare payments also include compulsory social insurance contributions, rents and housing costs. Additional expenses for special needs may also be covered.

\footnotetext{
${ }^{4} \mathrm{An}$ additional appendix attached to this paper provides selected descriptive statistics of our estimation sample.

${ }^{5}$ This reform was the last part of a series of four major reforms of the German labor market which were enacted between 2003 and 2005. These reforms have become known as 'Hartz reforms' named after the chairman of the commission proposing the reforms. Since the reform of the welfare system is the last of the four reforms it is also referred to as the 'Hartz IV reform'. See Jacobi and Kluve (2007) for a description of all four 'Hartz reforms'.
} 
In order to be eligible for UBII, persons have to be aged 15 to 64 years and be able to work for at least 15 hours per week. It is important to note that unemployment is not a prerequisite for receipt of UBII. Individuals who are employed but whose household income is too low are also eligible for UBII. Claimants capable of work have to register with the local welfare agency and are obliged to participate in welfare-to-work programs. This obligation marks an important change in German welfare policy. Namely, for the first time welfare recipients became a target group of labor market activation. Before 2005, hardly any effort was made to reintegrate these persons into the labor market and welfare solely relied on passive benefit payments. Since 2005 , the welfare recipients' rights and duties in the activation process are set out in a so-called 'integration contract' (Eingliederungsvereinbarung), an agreement between the welfare agency and the benefit recipient containing obligations with respect to program participation and job search activities, as well as detailing the services provided by the welfare agency. The integration contract is usually set up after the first meeting of a welfare recipient with the caseworker. The caseworker counsels and advises the welfare recipient and decides about placement in one of the various welfare-to-work programs.

Within the group of welfare recipients immigrants are clearly over-represented. In 2006, more than $34 \%$ of all welfare recipients were immigrants (Bundesministerium für Arbeit und Soziales, 2009) while their corresponding share of the population was only about $19.5 \%$ (see Statistisches Bundesamt, 2006). However, despite their over-representation in welfare, immigrants are not a specific priority group as for example young adults below the age of 25 , older welfare recipients, long-term unemployed persons, and women facing barriers to employment due to care obligations for children or older persons in the household. For this reason, German welfare lacks integration plans for immigrants that are offered in other countries like Denmark, Finland or Israel. ${ }^{6}$ Immigrants are placed in the standard welfare-to-work programs that have been designed for all welfare recipients. The most frequently used German welfare-to-work program are Temporary Extra Jobs.

\subsection{Temporary Extra Jobs}

Temporary Extra Jobs (Arbeitsgelegenheiten in der Mehraufwandsvariante) were newly introduced into the comprehensive set of German welfare-to-work programs within the 2005 reform of German welfare. They provide temporary work opportunities for particularly hard-to-place

\footnotetext{
${ }^{6}$ See Clausen, Heinesen, Hummelgard, Husted, and Rosholm (2009) for an evaluation of ALMP for immigrants in Denmark. The effects of a Finnish integration plan program are studied by Hämäläinen and Sarvimäki (2008). Cohen-Goldner and Eckstein (2009) analyze the integration programs for immigrants from the former Soviet Union to Israel.
} 
welfare recipients in order to maintain or enhance the employability of the participants and to improve the job chances for regular employment. For this reason, Temporary Extra Jobs should be used as a last resort of activation; they are by no means intended for the majority of needy people. Occupations in Temporary Extra Jobs have to be additional in nature, of value for society, and must not compete with regular jobs in the market. Activities are additional in nature if they would not be undertaken now or in the near future without the subsidy of the Federal Employment Agency (Bundesagentur für Arbeit, FEA), which pays a lump sum to organizations providing Temporary Extra Jobs. Occupations are of value for the society if the outcome is for the collective good. The last condition should rule out any deadweight losses and substitution effects (see Calmfors $(1994 ; 1995)$ for a detailed discussion of these effects for active labor market policy programs) that could result from the activities. Temporary Extra Jobs comprise numerous different types of jobs, but are quite frequently used for community services, long-term care activities or jobs in public infrastructure.

With regard to the eligibility conditions Temporary Extra Jobs resemble the formerly widely used Job Creation Schemes (Arbeitsbeschaffungsmaßnahmen). Moreover, similar to Job Creation Schemes that were intended for long-term unemployed persons only, participation in Temporary Extra Jobs is restricted to welfare recipients. Persons receiving solely unemployment benefits cannot be placed. However, given the disappointing impacts of Job Creation Schemes with regard to individual employment chances (see, e.g., Thomsen, 2007, or Hujer and Thomsen, 2010, for comprehensive analyses), several features of Temporary Extra Jobs are designed differently to avoid the unintended outcomes of the past. First of all, programs are clearly shorter and, in general, last for up to six months only. In addition, whereas in Job Creation Schemes and the other earlier employment programs participants were paid tariff wages or high lump sum payments, there is only a small remuneration in Temporary Extra Jobs. While engaged, persons continue to receive the UBII payments and the maintenance allowances. For the additional efforts in the program, they receive an additional hourly wage of between 1 and 2 Euro by the organization providing the Temporary Extra Job. ${ }^{7}$ Moreover, placement in a Temporary Extra Job does not constitute a regular employment relationship, i.e. participants remain welfare recipients and do not possess the rights and duties of regular employees. However, welfare recipients are not recorded unemployed during participation in Temporary Extra Jobs. An extensive use of these programs could therefore be used to reduce the official unemployment rate. Finally, to avoid locking-in effects that have been prevalent for employment programs in the past, jobs are usually part-time and amount to about 30 hours per week. This should enable

\footnotetext{
${ }^{7}$ For this reason, Temporary Extra Jobs are also called One-Euro-Jobs (Ein-Euro-Jobs) in Germany.
} 
persons to continue looking for regular employment. Nevertheless, full-time engagements are possible as well.

Despite the adjusted design of Temporary Extra Jobs and the lessons learned from Job Creation Schemes, it is a priori unclear whether the new program is more effective. Temporary Extra Jobs are intended to avoid or at least to reduce the loss of human capital associated with being unemployed and to provide participants with skills necessary for finding regular employment. However, the transferability of skills is questionable since Temporary Extra Jobs are additional in nature and regular employers might demand different skills. Similarly, participation in Temporary Extra Jobs could, on the one hand, act as a signal of welfare recipients to be willing to work. On the other hand, though, it could lead to stigmatization. If regular employers see Temporary Extra Jobs as a program targeted at the most disadvantaged persons, then participation may be seen as an adverse selection of welfare recipients with low productivity. Thus, the program effects are unclear ex-ante and a thorough investigation is needed.

Include Table 1 about here

To clarify the importance of such an investigation, Table 1 provides selected figures characterizing German welfare. The number of entitled persons to UBII amounts to about 5.0 million on annual average; however, referring to the years from 2006 onwards a slight decline from about 5.4 million to 5.0 million persons can be observed. The corresponding spending amounted to more than 30 billion Euro per year for passive UBII benefits. Corresponding to the shift in the number of entitled persons, spending declined slightly between 2006 and 2008. In contrast, the figures for the spending on welfare-to-work programs emphasize the increased importance of the newly introduced need to activate the former welfare recipients. Whereas in 2005 only 3.1 billion Euro were spent overall, this figure increased by more than 50 percent up to 4.7 billion Euro in 2008. Despite being designed as a last resort of activation, Temporary Extra Jobs are used extensively; within the scope of all welfare-to-work programs they outreach all other single programs. Except in 2005 when Temporary Extra Jobs were introduced, the numbers of newly promoted individuals amounted to more than 750,000 participants in each year. Considering the decline in the number of UBII benefits overall, the relative importance of Temporary Extra Jobs increased even more. In 2008, about 15 percent of welfare recipients were placed in a Temporary Extra Job.

Given the over-representation of immigrants in German welfare and the purpose of Temporary Extra Jobs to provide a last resort of activation for hard-to-place welfare recipients, we expect 
to perceive a high share of immigrant participants in the programs. However, this expectation does not come true when looking at the empirical numbers. In contrast, despite being a disadvantaged group immigrants are less often placed in Temporary Extra Jobs. Within the scope of all placements in welfare-to-work programs during the first quarter of welfare receipt, Bundesministerium für Arbeit und Soziales (2009) reports that 31\% of all native German participants in welfare-to-work programs are placed in Temporary Extra Jobs while the corresponding share for immigrants amounts to only $22 \% .^{8}$ In addition, immigrants are less often placed in welfare-to-work programs overall. Hence, the use of Temporary Extra Jobs is less pronounced for immigrants compared to natives; nevertheless, they are used extensively.

Due to the extensive use of Temporary Extra Jobs, the "last-resort" function of the program is hardly met. Two reasons may be responsible for this: First, regional labor demand conditions vary a lot across Germany. Hence, persons in welfare are not necessarily unemployable due to lack of productivity or lack of motivation, but regional and qualification mismatch have to be perceived important. If cost of qualification adjustment (in case of qualification mismatch) or cost of movement (regional mismatch) are extraordinarily high or not supported by the welfare agency, persons stay in the region. To maintain their employability, and for reasons related to social peace and health, persons are likely to be placed in Temporary Extra Jobs. Secondly, placing welfare recipients in welfare-to-work programs relieves the official unemployment register since participants are not counted as unemployed persons during participation. The incentives of the regional welfare agencies are closely linked to smaller numbers of welfare dependency and unemployment since gross drop-off rates are positively assessed. For both reasons, the massive use of programs is likely.

\section{Data}

For the empirical analysis, we use a sample of all inflows into welfare in Germany from January, 1st 2006 to December, 31st 2006. The data stem from administrative records of the FEA and were provided by the Institute for Employment Research, Nuremberg. To ensure that inflows in the data are not short-term recurrences of welfare episodes, for example due to false reporting or data errors, only persons who have not been registered in welfare for at least three months before the sampling date are regarded. The data were merged from five different sources of administrative records. The main source is the Integrated Employment Biography data set (Integrierte Erwerbsbiographien, IEB), which provides comprehensive information with regard to

\footnotetext{
${ }^{8}$ Numbers calculated from Table 8.1, p. 165 of Bundesministerium für Arbeit und Soziales (2009).
} 
the socio-demographic situation, the labor market history, and the participation in welfareto-work programs. The information included in IEB covers the years 1990 to 2007 and, thus, provides a sufficient source of background information for inflows into UBII in 2006. These data allow for quite a detailed characterization of the current situation and the labor market chances of the UBII recipients. However, since UBII entitlement is means-tested with consideration of the wealth and the income of further household members, we merge information on further persons living in the households that are recorded in the Benefit History Master Records (Leistungshistorikgrunddatei, BHMR).

In the empirical analysis, we distinguish the following ethnic groups: Immigrants comprise all foreigners and naturalized persons. Foreigners are persons who do not possess German citizenship. The naturalized group contains, on the one hand, German resettlers from Eastern Europe, and, on the other hand, naturalized foreigners. Although citizenship is recorded in IEB as well, identification of naturalized foreigners and German resettlers from Eastern Europe could only be obtained partially from this dataset. To identify resettlers we consider the information on the immigration date recorded in the Job Seeker Statistics (Arbeitsuchendenstatistik, ASU) dating back to 1990, which explicitly contains the information on resettler status. To identify naturalized foreigners, we use the information from the IEB for the years 1990 to 2007 and in addition the Employment History Records (Beschäftigtenhistorik, EHR) for the years 1975 to 1989. A person with German citizenship at the sampling date who was recorded being a foreigner in any spell since 1975 is treated as a naturalized. Unfortunately, the administrative records of the FEA contain neither information about the place of birth nor about the parents of the individual. Moreover, since minors (persons under 15 years of age) do not appear in any of these data sources, we are neither able to identify immigrants who were naturalized at an early age nor to distinguish first and second generation immigrants.

As the main purpose of any welfare-to-work program is to eliminate welfare dependency, we could use the drop-off rate from welfare as an outcome variable to evaluate the effects of Temporary Extra Jobs and to decompose the differences in the effects between immigrants and natives. However, elimination of welfare dependency does not solely depend on the direct effects for the individual under study but may result from changes in the household as well, e.g. if the income of the partner increases. Therefore, we estimate the effects of working in a Temporary Extra Job on the drop-off rate from welfare conditional on employment uptake of the individual. This outcome variable measures whether the program is able to improve the situation of a treated individual such that there is a transition to employment and welfare dependency is terminated. The variable can be observed on a monthly basis until July 2008 and has been merged from the 


\section{Employment Statistics Register (Beschäftigtenstatistik, ESR). ${ }^{9}$}

In line with the two empirical questions of the paper, i.e. the evaluation of the program effects for immigrants and natives and the decomposition of effect differences, the analysis sample was drawn in a 1:1 ratio of immigrants and native Germans on regional level. In a first step, 80,000 immigrants were randomly drawn from the total inflow population into welfare in 2006 . Then in a second step, for each immigrant randomly drawn from a welfare agency district, one native German was drawn from the same district resulting in an overall sample of about 160,000 welfare recipients. Therefore, immigrant-native German ratios are balanced across districts and should mitigate regional imbalances in the distribution of immigrants that could affect the estimates.

For the analysis presented here, the sample is restricted to unemployed welfare recipients aged 18 to 57 years at the sampling date. Although unemployment is not a prerequisite for receiving welfare benefits, it is required for participation in Temporary Extra Jobs. In addition, welfare recipients younger than 18 years are excluded so that the estimates are not affected by compulsory schooling. Welfare recipients aged 58 years and above are eligible for so-called relaxed welfare receipt. Within this scheme active job search is not required for benefit entitlement and claimants can rely on welfare until (early) retirement age. The final sample for the analysis contains 82,774 observations of which 39,430 are immigrants and 43,344 are natives. Using the information in the IEB, we identify for each person the first assigned program during the welfare spell and evaluate participation against nonparticipation in any other program at the time starting the program. In the group of immigrants, 1,840 of the 39,430 persons $(1,217$ men and 623 women) are assigned to a Temporary Extra Job during the first year of their welfare spell. Among the natives the corresponding number amounts to 3,532 treated individuals $(2,377$ men and 1,155 women).

Despite being intended to act as a last resort of activation, there has been evidence from the early post-reform period in 2005 that the target groups of Temporary Extra Jobs are only reached partially when caseworkers assign the program (see e.g. Hohmeyer and Kopf, 2009). Based on our data covering the years 2006 and 2007, we observe a somewhat more precise targeting than has been described in the literature so far. We find that persons aged less

\footnotetext{
${ }^{9}$ It has to be noted that due to delays in reporting by employers, the information available in the ESR has an up to two-year time lag. Therefore, in a first step the FEA forecasts the information and then in a second step the forecast is replaced by the actually reported information. Consequently, assessing contemporary effects of welfare-to-work programs is possible, but the results will be based purely on forecasted employment information. As the evaluation of program effects should be based on actually reported, rather than forecasted information, our observation period ends in July 2008. Data were extracted in February 2009. However, as the time lag between the corresponding date of information and the extraction from the ESR for our analysis amounted to only eight months, the relation between reported and forecasted data was extensively checked. Based on the results of Fröhlich, Kaimer, and Stamm (2004), the share of forecasted data used in the analysis amounts to between four and ten percent at maximum.
} 
than 25 are most likely to be assigned to a Temporary Extra Job. Moreover, the participation probability decreases with educational attainment and depends on the labor market history. Those individuals, who experienced a relatively large amount of unemployment before entering the welfare system, are more likely to participate in a Temporary Extra Job. The same is true for persons who spent a considerable part of the final two years before entering welfare out of labor force. In contrast, welfare recipients with a relatively high employment share are less likely to be treated. However, despite this tendency towards a more precise targeting, there is sufficient overlap in the characteristics of treated and non-treated welfare recipients which can be exploited for the identification of program effects. A similar reasoning applies when comparing treated immigrants and treated natives. Here, we observe only small differences. Immigrants are less frequently single and, thus, household size for immigrants is on average larger than for natives. Moreover, the variation in educational achievement is larger for immigrants than for natives. We observe a relatively large share of immigrants without any school leaving certificate, but also a noticeable share of persons with a university entrance diploma. Both ethnic groups are fairly similar with respect to the labor market history prior to program start. Small differences only exist in that immigrants are slightly more prone to have experienced unemployment. In addition, minor differences between treated natives and immigrants are visible in the lower end of the age distribution. While the share of immigrants aged between 18 and 24 is lower than for natives, the opposite is true for 25 to 34 aged individuals. However, despite these differences, there is again sufficient overlap in the distribution of covariates of immigrants and natives so that both groups are comparable with respect to the effectiveness of Temporary Extra Jobs.

\section{Evaluation Approach}

\subsection{Estimation of Treatment Effects}

The evaluation of the treatment effects of participation in Temporary Extra Jobs on the drop-off rate from welfare has to consider the set-up of the comprehensive system of welfare-to-work programs in Germany. This system is characterized by a wide array of programs which take place continuously over time and are open to welfare recipients who meet certain eligibility criteria, where participation can take place at different points of time during the welfare spell. Recent empirical literature highlights the need to consider the timing of treatment in the unemployment spell when evaluating treatment effects, see e.g. Abbring and van den Berg (2003), Sianesi (2004), Thomsen (2007), Fredriksson and Johansson (2008), or Hujer and Thomsen (2010). Whereas standard evaluation literature usually deals only with binary information, i.e. whether 
an individual has been subject to treatment or not, this literature points out the importance of information on the timing of treatment events as it conveys useful information for the identification of the treatment effect and has implications for the definition of the comparison groups. Specifically, the starting point of the program within the individual welfare spell may be an important determinant for the selection of participating individuals, as well as for the type of program the individual is assigned to.

The basis of the empirical analysis is given by the potential outcome approach of causality, comprehensively described in Heckman, LaLonde, and Smith (1999) and variously attributed to e.g. Neyman (1923), Roy (1951) and Rubin (1974). Following the conventional notation, let $Y^{1}$ and $Y^{0}$ denote the two potential outcomes, where $Y^{1}$ is the outcome when the individual participates in the program, and $Y^{0}$ is the outcome, when the individual does not participate. Since the individual cannot be in both states at the same time, one of the potential outcomes is unobservable and direct estimation of the treatment effect is impossible.

Therefore, to identify the treatment effect we have to provide an estimate of the unobserved state. We focus on the average effect of treatment on the treated (ATT) at some given elapsed welfare duration. Conditioning on the elapsed welfare duration is sensible in the German context for a reason first raised by Sianesi (2004). She argues that in a comprehensive active labor market policy system a person will join a program at some point, provided the individual remains in welfare long enough. Consequently, the reason why an individual is not observed as participating in a program is that the person has already left the welfare system, or the time horizon of the analysis is too short. Obviously, although participation in a program is not mandatory in Germany, like it is for instance in Sweden, it tends to be true that benefit recipients become more likely to participate in any program the longer they remain on welfare. The argument is therefore reasonable for the evaluation of Temporary Extra Jobs in Germany as well.

In line with that, participation and non-participation have to be defined dynamically, i.e. with respect to the point of time in which the comparison is made. According to Sianesi (2004), persons who have neither entered a program nor left welfare up to a specific point of time are defined as non-participants of interest or 'waiters' (in the sense that they are waiting to be allocated to a program). Thus, non-participation can be interpreted as the default state for each individual, and everybody is a non-participant until entering a program or leaving to take up a job. In this context, it should be noted that individuals who are defined as nonparticipants at the moment we start our comparison may enter a program at a later point in time. The evaluation approach in the dynamic setting could be formalized as follows. Let $U=$ 
$\left\{0, \ldots, U_{\max }\right\}$ define the discrete elapsed welfare duration of the individual since registration at the local welfare agency. Furthermore, let $u$ denote the point of time during the welfare spell in which the program of interest starts and $D_{u}$ the treatment indicator with the discrete time index. $D_{u}=1$ if the individual starts a program at time $u$ of the welfare spell, $D_{u}=0$ if the individual remains on welfare at $u$. Program effects are estimated for time $t$, i.e. the time since the program started. The hypothetical outcomes for time $t$ given a treatment at time $u$ are then defined as $Y_{t, u}^{1}$ for individuals who received the treatment at $u$ and $Y_{t, u}^{0}$ for individuals who did not receive the treatment at least up to time $u$. The parameter of interest for each $u$ is the average effect in $t$ for individuals starting a program in period $u$ of their welfare spell compared to not joining at $u$ :

$$
\begin{aligned}
\Delta_{t, u}^{A T T}= & E\left(Y_{t, u}^{1}-Y_{t, u}^{0} \mid D_{u}=1, D_{1}=\cdots D_{u-1}=0\right) \\
= & E\left(Y_{t, u}^{1} \mid D_{u}=1, D_{1}=\cdots D_{u-1}=0\right) \\
& -E\left(Y_{t, u}^{0} \mid D_{u}=1, D_{1}=\cdots D_{u-1}=0\right) .
\end{aligned}
$$

Whereas the first term is identified in the data by the observed outcome of the participants, the second term has to be estimated. Simply using the observable non-participants' outcomes to approximate the unobservable participants' outcomes without treatment may lead to biased estimates due to self-selection.

To solve the selection problem we apply a propensity score matching estimator. The basic idea of the matching approach is to find, in a large group of non-participants, those individuals who are similar to the participants in all relevant pre-treatment characteristics $X$ ('statistical twins'). However, it is well known that matching can become hazardous when $X$ is of high dimension. To deal with this dimensionality problem, Rosenbaum and Rubin (1983) suggest the use of the propensity score $p(X)=E(D=1 \mid X)$, i.e. the probability of participation in a program, summarizing the information of the relevant covariates $X$ into a single index function. However, for the ATT to be identified with matching, the so-called conditional independence assumption (CIA, $Y^{0} \amalg D \mid X$ in the static binary case, Lechner, 1998) has to be imposed. It states that, conditional on the set of relevant (observable) covariates $X$, the non-participation outcome $Y^{0}$ is independent of the participation decision.

For the dynamic case, we have to invoke an adjusted version, the dynamic conditional independence assumption (DCIA):

$$
Y_{t, u}^{0} \amalg D_{u} \mid p\left(X_{u}\right), D_{1}=\cdots=D_{u-1}=0,
$$

i.e. the hypothetical outcome at time $t$ after not participating up to time $u$ is independent of program participation at time $u$, conditional on the propensity score $p\left(X_{u}\right)$ measured at time 
$u$. The DCIA ensures that treated and non-treated individuals are comparable in their nontreatment outcomes at time $t$ conditional on $p\left(X_{u}\right)$, conditional on claiming welfare benefits up to time $u-1$, and conditional on not receiving treatment before $u$. In addition, the availability of non-participating analogues for the participants must be guaranteed (common support), i.e. $\operatorname{Pr}\left(D=1 \mid X_{u}\right)<1$ (Smith and Todd, 2005a).

For the DCIA to hold, it is necessary to observe all covariates that, conditional on having spent a given welfare duration $u$, jointly influence the participation decision at that time $\left(D_{u}\right)$ and the outcome variable where such a decision is postponed further $\left(Y_{t, u}^{0}\right)$. In line with that, we condition on previous welfare experience by stratifying the welfare duration in quarters. Using this kind of aggregation is useful for consideration of differences due to the timing of treatments since we expect the probabilities of entering a program or employment to remain relatively constant within quarters of the welfare spell. For the propensity scores, we have estimated separate probit models for each group, gender, and the first four quarters of welfare receipt. Each probit estimates the probability of starting a program in quarter $u$, conditional on $X$, conditional on having reached the welfare duration of $u \in\{1, \ldots, 4\}$ quarters, and conditional on not having received a treatment before $u$ in the welfare spell. Hence, we analyze the effects of Temporary Extra Jobs for groups of individuals that join within the first year of the welfare spell. The outcomes are measured monthly from the first month of the sequent quarter after (potential) participation onwards until July 2008 due to the time horizon of the analysis. ${ }^{10}$

\subsection{Decomposition of Differences in Treatment Effects}

Considering effect heterogeneity in the treatment effects between ethnic groups for a particular program can be used to reveal important insights. Assuming that identical programs are provided, differences could be, on the one hand, due to differences in the composition of the groups, i.e. the distribution of characteristics that are relevant for program and labor market success may be different. Hence, when conditioning on all these variables no further differences should occur. However, on the other hand, if residual differences would remain between the compared ethnic groups these differences are solely due to the ethnic group attachment of the individual and might be interpreted as potential discrimination. An important question in the context of providing welfare-to-work programs for immigrants is whether potential discrimination is iden-

\footnotetext{
${ }^{10}$ For programs assigned in the first quarter of the welfare spell we have an observation period of at least 16 months for each observation. The last entry into the welfare system in our sample is December 31st, 2006. Thus, a program in the first quarter could be assigned until March 31st, 2007. In this case, the observation period for the outcomes is April 2007 until July 2008. Consequently, for programs assigned in the second quarter we have an observation period of 13 months. In the third quarter the observation period lasts for 10 months and in the fourth quarter for 7 months.
} 
tified as the unexplained part of the gap in the difference of the treatment effects. To analyze the extent of the potential discrimination, we follow Aldashev, Thomsen, and Walter (2010) and apply the following decomposition procedure.

To abbreviate notation, we suppress the indicators of the dynamic setting. The starting point for the decomposition is the raw differential $\Delta_{D i f}^{A T T}$ of the differences in the ATTs between immigrants and native Germans:

$$
\Delta_{D i f}^{A T T}=\Delta_{M i g}^{A T T}-\Delta_{n G}^{A T T}
$$

with

$$
\Delta_{M i g}^{A T T}=\left.E\left(Y^{1}-Y^{0} \mid X_{M i g}, D=1\right)\right|_{M i g=1},
$$

and

$$
\Delta_{n G}^{A T T}=\left.E\left(Y^{1}-Y^{0} \mid X_{n G}, D=1\right)\right|_{M i g=0} .
$$

Here, $\Delta_{M i g}^{A T T}$ denotes the ATT for the immigrants and $\Delta_{n G}^{A T T}$ is the ATT for the native Germans who participated in Temporary Extra Jobs.

To highlight the differences in the raw differential, we have added the relevant conditions in eq. (4) and (5). Mig is a dummy variable taking value 1 if the group of interest are immigrants, and 0 if native Germans are considered. Moreover, the ATT of the immigrants (eq. 4) is conditional on the observable characteristics $X_{M i g}$ of the participating immigrants and the ATT for the native Germans (eq. 5) is conditional on the characteristics $X_{n G}$ of the participants in that group.

Accordingly, we could decompose the raw differential in eq. (3) into a part which is explained by differences in observable characteristics and a residual part which cannot be explained by observables:

$$
\Delta_{\text {Dif }}^{A T T}=\Delta_{\text {explained }}^{A T T}+\Delta_{\text {residual }}^{A T T} .
$$

The first term on the right-hand side denotes the part of the difference in the ATTs for immigrants and native Germans that is explained by differences in observable characteristics (e.g. due to a different age or qualification structure). This part is defined as

$$
\Delta_{\text {explained }}^{A T T}=\left.E\left(Y^{1}-Y^{0} \mid X_{M i g}, D=1\right)\right|_{M i g=0}-\left.E\left(Y^{1}-Y^{0} \mid X_{n G}, D=1\right)\right|_{M i g=0} .
$$

It is the difference in ATTs for the native participants when conditioning first on the observable characteristics $X_{M i g}$ of the participating immigrants and second on the observables $X_{n G}$ of the participating native Germans. If $X_{M i g}$ and $X_{n G}$ are identical, $\Delta_{\text {explained }}^{A T T}$ will be 0 and the difference in ATTs for immigrants and natives is not attributable to differences in observables 
between the two ethnic groups. However, if $X_{M i g} \neq X_{n G}$, then $\Delta_{\text {explained }}^{\text {ATT }}$ will in general be nonzero and measure differences in ATTs between immigrants and natives due to observable characteristics.

The second term on the right-hand side of eq. (6) denotes the difference in the ATTs for immigrants and native Germans that is solely due to unobservable differences between the two groups. Holding the observable characteristics constant, i.e. assuming all individuals to possess the characteristics $X_{M i g}$ of the immigrants, the difference is defined as:

$$
\Delta_{\text {residual }}^{A T T}=\left.E\left(Y^{1}-Y^{0} \mid X_{M i g}, D=1\right)\right|_{M i g=1}-\left.E\left(Y^{1}-Y^{0} \mid X_{M i g}, D=1\right)\right|_{M i g=0} .
$$

It is the difference in ATTs between immigrants and natives when conditioning in both cases on the covariates $X_{M i g}$ of the participating immigrants. If covariates $X_{M i g}$ are valued equally in both ethnic groups, then $\Delta_{\text {residual }}^{A T T}=0$ and the difference in ATTs does not depend on unobservable characteristics. However, if covariates $X_{M i g}$ are valued differently, then $\Delta_{\text {residual }}^{\text {ATT }}$ is non-zero and measures the unexplained part of the raw differential $\Delta_{D i f}^{A T T}$.

Thus, the proposed decomposition of the differences in the treatment effects is similar to a difference-in-differences estimator. It allows the ceteris paribus identification of the difference in program effects that is due to variation in observable characteristics, i.e. differences in the composition of the immigrant and native participants in Temporary Extra Jobs, and of the part that is due to belonging to the immigrant group. The latter relates to unobservable differences between immigrants and native Germans. We will refer to this part as an immigrant fixed effect.

To estimate the difference that is due to unobservable differences (eq. 8), we have to match participating immigrants with comparable participating native Germans, i.e. $X_{M i g}=X_{n G}$. To do so, we apply a matching procedure similar to that described above. In the first step, we estimate the ATTs separately for both ethnic groups, for both genders and for the considered four quarters. In the second step, we keep only the participants in each sample and match treated immigrants and treated native Germans conditional on the distribution of the observable characteristics of the treated immigrants. Outcome variable in this matching step is the individual treatment effect from the Temporary Extra Job for each participant. Therefore, the resulting effect of the second matching step gives us the average difference in program effects between immigrants and natives which is due to the immigrant fixed effect keeping all observable characteristics constant. 


\subsection{Implementation}

For both matching steps we apply a kernel density matching on the estimated propensity score. Standard errors are calculated by bootstrapping with 250 replications. With regard to the variables selected as relevant to solve the potential self-selection bias, the comprehensive data at hand provides a sufficient basis. In the empirical specification of the propensity score models, we use 21 categories of variables comprising socio-demographic information like age, marital status, or the number of children, the qualification of the individual and information characterizing the employment, unemployment, and welfare history dating in some cases back until 1990. The specifications for the final models used in the estimations were obtained by estimating probit regressions starting with the full set of variables and a stepwise dropping of jointly insignificant variable-blocks (indicated by $F$-tests) in order to provide a parsimonious specification. For this reason, the model specifications vary across the probit models estimated. In particular, they vary in the first matching step across ethnic groups, quarters of program start, and gender.

The estimated propensity scores should guarantee that the included variables are balanced between treatment and comparison group. To check the balancing property of the estimated propensity score $(\hat{p})$, we applied the test suggested by Smith and Todd (2005b):

$$
\begin{aligned}
X_{k_{u}}= & \beta_{0}+\beta_{1} \hat{p}\left(X_{u}\right)+\beta_{2} \hat{p}\left(X_{u}\right)^{2}+\beta_{3} \hat{p}\left(X_{u}\right)^{3}+\beta_{4} \hat{p}\left(X_{u}\right)^{4} \\
& +\beta_{5} D+\beta_{6} D \hat{p}\left(X_{u}\right)+\beta_{7} D \hat{p}\left(X_{u}\right)^{2}+\beta_{8} D \hat{p}\left(X_{u}\right)^{3}+\beta_{9} D \hat{p}\left(X_{u}\right)^{4} .
\end{aligned}
$$

This test was done both for the estimation of program effects and for the decomposition of treatment effects between the two ethnic groups. Therefore, the treatment indicator $D$ in eq. (9) denotes either program participation or immigrant status. The equation was estimated for each variable $X_{k_{u}}$ included in the respective propensity score specification. Afterwards, the null hypothesis of $\beta_{5}$ to $\beta_{9}$ being jointly zero was tested. The test indicates, whether there are differences due to the treatment indicator conditional on a quartic polynomial of the propensity score. If ideal balancing is achieved all those coefficients should be zero.

Obviously, caseworkers play a crucial role in the process of assignment to programs. Turning down a placement could be sanctioned by benefit revocation and, hence, caseworkers can be assumed to have the final word in the participation decision. If the caseworkers act on unobservable information that is correlated with the individual's potential labor market outcomes, the DCIA would be violated in the first matching step when estimating program effects. However, it is not very likely that caseworkers have referred to further unobservable information than the large set of variables recorded. The data used in this analysis were collected by the caseworkers 
and supplemented by their own subjective assessment of the qualification and placement restrictions of the individuals. Moreover, it should be noted that - to bias the estimates - any further unobserved information has to jointly influence the participation decision and the outcomes. Given the large set of variables we considered relevant and we controlled for in the estimations, we assume that caseworkers act idiosyncratically given the observable characteristics of the individuals and the subjective assessments.

For interpretation of the program effects, one has to bear in mind that the chosen comparison group does not reflect a no-program state, but rather possibly postponed participation. If we choose as the comparison group those individuals who have been observed to never participate in the data, this may invalidate the DCIA, as we have to condition on future outcomes. For unbiased estimation we have to rule out anticipatory effects, else people would behave differently conditional on future outcomes or treatments. If for example, non-participants would know in advance that they would be treated later and when this would occur, then matching could not solve the selection problem and we would overestimate the treatment effect since the nonparticipants have no reason to leave welfare instantly for work. In contrast, if people dread the prospect of being treated and, again, they know when to be treated in the future they will leave for work and the program effect is underestimated since non-participants would differ significantly from the participants even after matching. However, it is important to note that this is only the case if people know exactly that they will be treated and when. In line with that, Abbring and van den Berg (2003) point out that the exclusion of anticipatory effects does not rule out that the individuals know and act on the determinants of assignment to treatment or labor market outcomes, i.e. individuals are allowed to adjust their optimal behavior to the determinants of the treatment process, but not to realization of the treatment. This is not a problem for the analysis as long as treated and non-treated individuals anticipate the chances of these events conditional on the propensity score and the elapsed welfare duration in a certain quarter in the same way. Hence, with respect to the assignment process during the individual welfare spell people may know the determinants, but it is unlikely that they know the realizations of the future events. For that reason, we assume our estimates not to be affected by anticipatory effects. 


\section{Empirical Results}

\subsection{Quality of the Estimates}

For the estimation of program effects we stratify our data by ethnic group, gender and quarter of program start. In total we estimate treatment effects for 16 different strata. To obtain valid treatment effects it is crucial that the covariates included in the propensity score estimation are balanced between treatment and comparison group after matching. As a balancing test we apply the procedure suggested by Smith and Todd (2005b). Results of this test are summarized in Table 2. The test is passed in $94,4 \%$ or 865 of 916 cases at the $1 \%$ significance level. Thus, balancing is not ideal in every case but sufficient to obtain valid treatment effects. The matching quality is similar for men $(94.3 \%, 447$ of 474 tests passed) and women $(94,5 \%, 418$ of 442) as well as for natives $(93.9 \%, 430$ of 458$)$ and immigrants $(95.0 \%, 435$ of 458). Even at the 5\% level 816 of the total 916 tests are passed and 777 at the $10 \%$ level.

Include Table 2 about here

The exact specifications of the estimated 16 propensity scores cannot be presented here, but are available upon request from the authors. Results reveal, that especially age, educational attainment, professional qualification, household composition, region, and employment history within the last six years, in particular during the final 24 months before entering the welfare system, are relevant factors that must be accounted for when estimating the effects of Temporary Extra Jobs. It turns out that these covariates are also important in the second matching step when decomposing differences in program effects between immigrants and natives. Table 3 summarizes the results of the Smith and Todd (2005b) balancing test for this matching step. As can be seen from the table, covariates are balanced very well and matching quality is of the same high degree as in the first matching step. Thus, in both steps of the analysis the matching approach allows us to compare similar groups of treated and non-treated welfare recipients and of treated immigrants and treated natives, respectively, since the identification strategy cancels out the observed differences in pre-treatment characteristics, which have been described in section 3 .

Include Table 3 about here 


\subsection{Program Effects}

The estimated program effects and corresponding t-values are displayed in Table 4 . The effects are estimated separately for natives and immigrants, for men and women and for each quarter. ${ }^{11}$ As can be seen from the table, Temporary Extra Jobs assigned during the first quarter of a welfare spell have a negative impact on the probability of immigrant males to take up employment providing a sufficient income above the subsistence level. Surprisingly, we observe only a modest locking-in effect of -1 percentage point in the first six months after program start which lacks statistical significance. However, the absolute size of the negative treatment effect increases over time. One year after program start, participants have a 2.7 percentage point lower probability to take up employment than in a situation without treatment. Thus, Temporary Extra Jobs reduce rather than increase the employment chances of male immigrants. For men without migration background who participate in the program during the first quarter of their welfare spell, the negative treatment effects are even stronger. Here, we observe treatment effects ranging between -2.5 and -4.1 percentage points. The effect is strongest at the beginning of the observation period indicating a substantial locking-in effect, but even one year after starting the program the probability of participants to take up employment is 3.1 percentage points lower than in the case without participation. Therefore, the adverse effect of Temporary Extra Jobs one year after program start is somewhat larger for native than for immigrant males (-3.1 vs. -2.7 percentage points).

Include Table 4 about here

A similar pattern is observed for Temporary Extra Jobs starting in the second quarter of welfare receipt. Here, we estimate negative treatment effects for participating immigrants ranging between -1.9 and -4.4 percentage points. These effects are clearly stronger than in the first quarter but less adverse compared to the effects for natives starting a Temporary Extra Job at the same time. For this group we estimate locking-in effects of -5.7 percentage points during the first six months after program start. Thereafter, the absolute size of the treatment effect reduces only a little. It still amounts to -4.4 percentage points twelve months after program start.

For Temporary Extra Jobs starting in the third or fourth quarter of welfare receipt, the treatment effects range between -1.4 and -3.1 percentage points for native males. Thus, the program

\footnotetext{
${ }^{11}$ We report treatment effects only for up to one year after program start, even though we have an observation period of 16 months for Temporary Extra Jobs starting during the first quarter of welfare receipt. However, estimates after 16 months do not differ significantly from the results obtained after 12 months. In particular, we do not observe any significantly positive treatment effect in any estimation after locking-in effects fade away.
} 
clearly fails to achieve its objectives in these quarters, too. In contrast, for immigrant males, who take up a Temporary Extra Job during the third and fourth quarter of their welfare spell, we do not estimate any significant treatment effect. Unlike the first two quarters and unlike the picture observed for natives, effects tend to be positive. Thus, even though the program again does not achieve its objectives, it at least does not reduce employment chances.

As in the case of native men, we also estimate solely negative treatment effects for female natives irrespective of the timing of the assignment to a Temporary Extra Job. For women without migration background who participate in the program during the first quarter of their welfare spell, we observe treatment effects ranging between -1.1 and -2.5 percentage points, which are, however, statistically insignificant. In the second quarter, the negative treatment effects are more pronounced and amount to about -3 percentage points throughout the whole observation period. Thus, similarly to men, the second quarter exhibits the most adverse treatment effects for women, too. For Temporary Extra Jobs assigned during the third and fourth quarter of the welfare spell, we only observe significant locking-in effects up to three months after program start.

A similar result is found for female immigrants participating in Temporary Extra Jobs during the first quarter after entering the welfare system. Here, the negative locking-in effect is significant only in the first three months after program start and amounts to -3.9 percentage points. Thereafter, the estimate turns to be statistically insignificant. Female immigrants treated in the second quarter face much more adverse treatment effects. Participating in a Temporary Extra Job at this time reduces the probability to take up employment by 3 to 4 percentage points throughout the whole observation period. In the third quarter statistically significant locking-in effects can be observed until the sixth month after program start. Thereafter, the sign of the estimate turns positive but the effect is statistically insignificant. For Temporary Extra Jobs assigned in the fourth quarter no significant impact is found.

Our results are in line with previous empirical evidence. Similar to Hohmeyer and Wolff (2007), Hohmeyer (2009) and Huber, Lechner, Wunsch, and Walter (2010) we do not find any positive employment effect about one year after program start. However, our results cast doubt on the view that there might be significantly positive treatment effects in the long run as for example found by Hohmeyer and Wolff (2007). Our estimates for female welfare recipients are quite stable over the whole observation period and for male immigrants, who participate in a Temporary Extra Job during the first quarter of their welfare spell, we even find that the negative treatment effect increases in absolute terms over time. Thus, Temporary Extra Jobs are a dead-end road in welfare rather than a merging lane to regular employment. 


\subsection{Decomposition Results}

The previous subsection showed that the treatment effects of Temporary Extra Jobs are mainly negative for immigrant and native participants, but differ to some extent since the effects are somewhat more adverse for natives. Therefore, the question arises what might cause these differences. Are they due to differences in the observable characteristics of the two groups or are they due to unobservable differences subsumed in the immigrant fixed effect? To disentangle the influence of both possible explanations we decompose the differences in the treatment effects between immigrants and natives in two parts: the part which is caused by differences in observables and the residual part due to the immigrant fixed effect. Differences due to the immigrant fixed effect are of major policy concern, since in this case discrimination in the effectiveness of Temporary Extra Jobs is present. Therefore, in the following we concentrate on differences in treatment effects due to unobservables. Table 5 displays the relevant results.

Include Table 5 about here

The first row of each block in the table depicts the raw differential of differences in the ATTs between immigrants and native Germans participating in Temporary Extra Jobs. This raw differential is calculated from the results presented in the previous subsection. The p-value denotes statistical significance of the difference in ATTs of immigrants and natives. The third row of each block in the table is denoted by $\Delta_{\text {residual }}^{A T T}$ and shows the estimated part of the raw differential which is due to the immigrant fixed effect. In other words, $\Delta_{\text {residual }}^{A T T}$ indicates by how much the treatment effect of a program is changed due to the migration background holding all other factors fixed. The t-value denotes statistical significance of the immigrant fixed effect.

The entry 0.0331 in the top left block of Table 5 states that three months after program start the ATT for male immigrants participating in Temporary Extra Jobs during the first quarter of their welfare spell is by 3.3 percentage points larger than for treated natives. This difference is statistically significant at the $5 \%$-level and cannot be explained by observable differences in the characteristics of natives and immigrants. Rather, it must be attributed to the immigrant fixed effect. If all other characteristics would be kept constant, immigrants would even have a 3.6 percentage point larger treatment effect than natives. Therefore, immigrants benefit more from Temporary Extra Jobs than identical men without migration background. However, this immigrant fixed effect decreases over time and loses its statistical significance already six months after the program is assigned. A reversed picture is observed for women participating in Temporary Extra Jobs during the first quarter of the welfare spell. Here, the immigrant 
fixed effect increases over time and reaches a maximum of nearly 7 percentage points nine months after program start. Thus, as in the case of men, female immigrants benefit more from Temporary Extra Jobs than natives keeping everything else constant.

In the second quarter the immigrant fixed effect tends to be positive as well. However, it is statistically insignificant for both genders during the whole observation period. For Temporary Extra Jobs starting in the third quarter of welfare receipt, we observe a positive immigrant fixed effect for male participants again. This positive effect is statistically significant from the sixth month onwards and amounts to about 6 percentage points. Thus, netting out all observable differences between immigrants and natives, the former have on average a 6 percentage point larger treatment effect than the latter. For women who participate in Temporary Extra Jobs in the third quarter of their welfare spell, we do not find statistically significant differences between the two ethic groups. Here, as opposed to men, the immigrant fixed effect is of negative sign indicating that immigrants tend to benefit less from the Temporary Extra Job than otherwise identical natives. Although the immigrant fixed effect is insignificant, it is of considerable size in absolute terms. In the fourth quarter the immigrant fixed effect is again positive for both genders. The estimated effects are substantial but only slightly significant for females at the end of the observation period.

\section{Conclusion}

Temporary Extra Jobs are the most frequently used single welfare-to-work program in Germany since the reform of the welfare system in 2005. The program provides temporary work opportunities for welfare recipients who are granted a small compensation in addition to welfare and maintenances allowances and are intended to maintain and improve the employability of the participants for (later) re-integration into regular employment. Although eligibility of participation should be restricted with respect to the placement chances of the individual, i.e the participating welfare recipients should neither be directly placeable in employment nor in other welfare-to-work programs, this is hardly true in practice. With more than 750,000 welfare recipients promoted in Temporary Extra Jobs each year or about 15 percent of all welfare recipients, the "last-resort" function of the program is hardly met. In addition, although immigrants are a disadvantaged group, compared to natives they are less often placed in welfare-to-work programs overall and in Temporary Extra Jobs in particular. Nevertheless, Temporary Extra Jobs are also extensively used for immigrants.

Based on comprehensive administrative data on immigrant and native welfare recipients in 
Germany, we have evaluated the effects of participation on the drop-off rate from welfare by taking up employment. The particular focus of the analysis was the investigation of whether program effects differ between the two ethnic groups and what might cause these differences. As indicated by the empirical estimates, instead of increasing employment chances Temporary Extra Jobs rather reduce the probability of participants to take up a regular job providing a sufficient income above the subsistence level. Treatment effects are especially adverse if a Temporary Extra Job is started during the second quarter of a welfare spell. Even though program effects for immigrants are in many cases not as unfavorable as for natives, Temporary Extra Jobs are not an effective activation measure for this group either. The decomposition of the differences in treatment effects shows that immigrants benefit more from Temporary Extra Jobs than natives with otherwise identical characteristics. However, using this result to derive the conclusion that Temporary Extra Jobs should be more frequently used for immigrants is misleading. The strong negative treatment effects Temporary Extra Jobs exhibit for both ethnic groups indicate that the program fails to achieve its objectives. The effects are more adverse for natives, but the program does not help immigrants to leave the welfare system either. Temporary Extra Jobs are a dead-end road in welfare rather than a merging lane to regular employment both for immigrants and for natives. 


\section{References}

Abbring, J. H., And G. J. VAn Den Berg (2003): "The Nonparametric Identification of Treatment Effects in Duration Models," Econometrica, 71(5), 1491-1517.

Aldashev, A., S. Thomsen, And T. Walter (2010): "Short-Term Training Programs for Immigrants: Do Effects Differ from Natives and Why?," Discussion Paper No. 10-021, ZEW, Mannheim.

Blank, R. (2002): "Evaluating Welfare Reform in the United States," Journal of Economic Literature, 60, 1105-1166.

Bundesagentur für Arbeit (2006): "Arbeitsmarkt 2005," Amtliche Nachrichten der Bundesagentur für Arbeit 54, Nuremberg.

Bundesagentur für Arbeit (2007): "Arbeitsmarkt 2006," Amtliche Nachrichten der Bundesagentur für Arbeit 55, Nuremberg.

Bundesagentur für Arbeit (2008): “Arbeitsmarkt 2007," Amtliche Nachrichten der Bundesagentur für Arbeit 56, Nuremberg.

Bundesagentur für Arbeit (2009a): "Arbeitsmarkt 2008," Amtliche Nachrichten der Bundesagentur für Arbeit 57, Nuremberg.

Bundesagentur für Arbeit (2009b): "Jahresbericht 2008," SGB II - Sozialgesetzbuch Zweites Buch - Grundsicherung für Arbeitsuchende 3, Nuremberg.

Bundesministerium für Arbeit und Soziales (2009): "Wirkungen des SGB II auf Personen mit Migrationshintergrund. Abschlussbericht. Hauptband.," Forschungsbericht 395, Berlin.

Calmfors, L. (1994): “Active Labour Market Policy and Unemployment - A Framework for the Analysis of Crucial Design Features," OECD Economic Studies, 22, 7-47.

— (1995): "Labour Market Policy and Unemployment," European Economic Review, $39(3+4), 583-592$.

Clausen, J., E. Heinesen, H. Hummelgard, L. Husted, and M. Rosholm (2009): "The Effect of Integration Policies on the Time Until Regular Employment of Newly Arrived Immigrants: Evidence from Denmark," Labour Economics, 16, 409-417. 
Cohen-Goldner, S., And Z. Eckstein (2009): "Estimating the Return to Training and Occupational Experience: The Case of Female Immigrants," Journal of Econometrics, doi:10.1016/j.jeconom.2009.09.009.

Finn, D. (2000): "Welfare to Work: the local dimension," Journal of European Social Policy, $10,43-57$.

Fredriksson, P., And P. Johansson (2008): "Dynamic Treatment Assignment - The Consequences for Evaluations Using Observational Data," Journal of Business 63 Economics Statistics, 26(4), 435-445.

FrÖhlich, S., S. Kaimer, and M. Stamm (2004): "Beschreibung und Qualitätsanalyse Verbleibsnachweis in Beschäftigung," Internal Working Paper, IAB, Nuremberg.

Halverson, R., And P. Jensen (2004): “Activation in Scandinavian Welfare Policy," European Societies, 6, 461-483.

HämÄLÄInen, K., And M. SARVimäKi (2008): "Moving Immigrants from Welfare to Work: The Impact of an Integration Program," unpublished paper, Government Institute for Economic Research (VATT), Helsinki.

Heckman, J. J., R. J. LaLonde, and J. A. Smith (1999): "The Economics and Econometrics of Active Labor Market Programs," in Handbook of Labor Economics, ed. by O. Ashenfelter, and D. Card, vol. 3A, chap. 31, pp. 1865-2097. Elsevier, Amsterdam.

Hohmeyer, K. (2009): "Effectiveness of One-Euro-Jobs: Do programme characteristics matter?," Iab-discussion paper 20/2009, IAB.

Hohmeyer, K., And E. Kopf (2009): "Who is Targeted by One-Euro-Jobs? A Selectivity Analysis," Schmollers Jahrbuch, 129(4), 597-636.

Hohmeyer, K., and J. Wolff (2007): "A fistful of Euros: Does One-Euro-Job participation lead means-tested benefit recipients inot regular jobs and out of unemployment benefit II receipt?," Iab-discussion paper 8/2007, IAB.

Huber, M., M. Lechner, C. Wunsch, and T. Walter (2010): "Do German Welfare-toWork Programmes Reduce Welfare and Increase Work?," German Economic Review, forthcoming.

Hujer, R., And S. L. Thomsen (2010): "How Do Employment Effects of Job Creation Schemes Differ with Respect to the Foregoing Unemployment Duration," Labour Economics, 17(1), $38-51$. 
Jacobi, L., And J. Kluve (2007): "Before and After the Hartz Reforms. The Performance of Active Labour Market Policy in Germany," Journal for Labour Market Research, 40, 45-64.

Kluve, J. (2010): "The Effectiveness of European Active Labor Market Programs," Labour Economics, forthcoming.

Kluve, J., And C. Schmidt (2002): "Can Training and Employment Subsidies Combat European Unemployment?," Economic Policy, 35, 411-448.

Lechner, M. (1998): Training the East German Labour Force. Microeconometric Evaluations of Continuous Vocational Training after Unification. Physica-Verlag, Heidelberg.

Martin, J., And D. Grubb (2001): "What Works and for Whom: A Review of OECD Countries' Experiences with Active Labour Market Policies," Swedish Economic Policy Review, 8, $9-56$.

Moffit, R. (2002): "Welfare Programs and Labor Supply," vol. 4 of Handbook of Public Economics, chap. 34, pp. 2393-2430. Elsevier, Amsterdam.

Neyman, J. S. (1923): "On the Application of Probability Theory to Agricultural Experiments. Essays on Principles. Chapter 9," Statistical Science, 5(4), 463-480, Reprint in English from 1990.

OECD (2008): "International Migration Outlook: SOPEMI - 2008 Edition," Social Issues/Migration/Health 14, Paris.

Rosenbaum, P. R., and D. B. Rubin (1983): "The Central Role of the Propensity Score in Observational Studies for Causal Effects," Biometrika, 70(1), 41-50.

Roy, A. D. (1951): "Some Thoughts on the Distribution of Earnings," Oxford Economic Papers, 3(2), 135-145.

Rubin, D. B. (1974): "Estimating Causal Effects to Treatments in Randomised and Nonrandomised Studies," Journal of Educational Psychology, 66, 688-701.

SiAnesi, B. (2004): "An Evaluation of the Active Labour Market Programmes in Sweden," The Review of Economics and Statistics, 86(1), 133-155.

Smith, J. A., And P. Todd (2005a): "Does Matching Overcome LaLonde's Critique of Nonexperimental Estimators?," Journal of Econometrics, 125(1/2), 305-354. 
(2005b): "Does Matching Overcome LaLonde's Critique of Nonexperimental Estimators? Rejoinder," Journal of Econometrics, 125(1/2), 365-375.

Statistisches Bundesamt (2006): Leben in Deutschland. Haushalte, Familien und Gesundheit Ergebnisse des Mikrozensus 2005. Statistisches Bundesamt, Wiesbaden.

Thomsen, S. L. (2007): Evaluating the Employment Effects of Job Creation Schemes in Germany, vol. 36 of $Z E W$ Economic Studies. Physica-Verlag, Heidelberg. 
Table 1: Unemployment Benefits II and Temporary Extra Jobs

\begin{tabular}{lrrrr}
\hline \hline & 2005 & 2006 & 2007 & 2008 \\
\hline Persons entitled to UBII (avg. annual stock) $^{\mathrm{a}}$ & $4,981,748$ & $5,392,166$ & $5,276,835$ & $5,009,656$ \\
Spending for UBII (in billion Euro) $^{\mathrm{b}}$ & 32.8 & 34.7 & 31.5 & 30.2 \\
Spending for active labor market policy and welfare-to-work pro- $^{\text {grams (overall, in billion Euro) }}$ & 3.1 & 3.8 & 4.2 & 4.7 \\
New Participants in Temporary Extra Jobs $^{\mathrm{b}}$ & & & & \\
Ratio $^{c}$ & 604,051 & 775,866 & 759,257 & 764,212 \\
\hline \hline
\end{tabular}

${ }^{\text {a }}$ Figures obtained from Bundesagentur für Arbeit (2006, 2007, 2008, 2009).

${ }^{\mathrm{b}}$ Figures obtained from Bundesagentur für Arbeit (2009b).

${ }^{\mathrm{c}}$ Ratio denotes the relation of entries into Temporary Extra Jobs to persons entitled to UBII.

Table 2: Results for Smith and Todd (2005b) balancing test

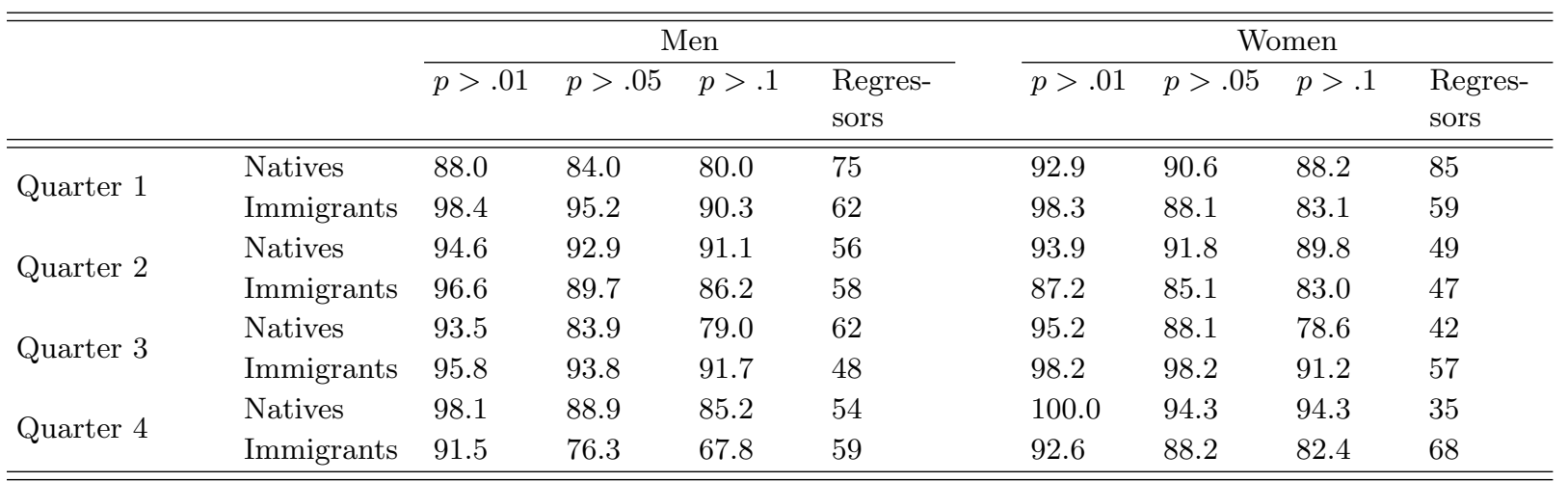

Remarks: Displayed is the percentage of variables passing the Smith and Todd (2005) balancing test at the 1\%-, 5\%- and 10\%-level. The column Regressors displays the absolute number of regressors used in the respective propensity score specification.

Table 3: Smith and Todd (2005b) balancing test for decomposition

\begin{tabular}{|c|c|c|c|c|c|c|c|c|}
\hline & \multicolumn{4}{|c|}{ Men } & \multicolumn{4}{|c|}{ Women } \\
\hline & $p>.01$ & $p>.05$ & $p>.1$ & $\begin{array}{l}\text { Regres- } \\
\text { sors }\end{array}$ & $p>.01$ & $p>.05$ & $p>.1$ & $\begin{array}{l}\text { Regres- } \\
\text { sors }\end{array}$ \\
\hline Quarter 1 & 93.2 & 89.8 & 86.4 & 59 & 95.3 & 93.0 & 93.0 & 43 \\
\hline Quarter 2 & 100.0 & 97.6 & 97.6 & 41 & 93.2 & 88.6 & 88.6 & 44 \\
\hline Quarter 3 & 100.0 & 98.6 & 94.2 & 69 & 96.5 & 95.3 & 95.3 & 85 \\
\hline Quarter 4 & 94.2 & 84.6 & 82.7 & 52 & 98.3 & 96.6 & 96.6 & 58 \\
\hline
\end{tabular}

Remarks: Displayed is the percentage of variables passing the Smith and Todd (2005) balancing test at the 1\%-, 5\%- and 10\%-level. The column Regressors displays the absolute number of regressors used in the respective propensity score specification. 
Table 4: Estimated treatment effects

\begin{tabular}{|c|c|c|c|c|c|c|c|c|}
\hline \multirow[b]{2}{*}{ Month after program start: } & \multicolumn{4}{|c|}{ Men } & \multicolumn{4}{|c|}{ Women } \\
\hline & 3 & 6 & 9 & 12 & 3 & 6 & 9 & 12 \\
\hline Quarter 1 & \multicolumn{4}{|c|}{ Treated: 889 natives and 428 immigr. } & \multicolumn{4}{|c|}{ Treated: 347 natives and 193 immigr. } \\
\hline \multirow{2}{*}{ Natives } & -0.0410 & -0.0254 & -0.0263 & -0.0312 & -0.0105 & -0.0261 & -0.0249 & -0.0200 \\
\hline & -4.59 & -2.38 & -2.26 & -2.53 & -0.64 & -1.42 & -1.29 & -0.93 \\
\hline \multirow{2}{*}{ Immigrants } & -0.0080 & -0.0129 & -0.0242 & -0.0272 & -0.0390 & -0.0119 & 0.0152 & -0.0090 \\
\hline & -0.59 & -0.86 & -1.55 & -1.62 & -3.06 & -0.59 & 0.59 & -0.36 \\
\hline Quarter 2 & \multicolumn{4}{|c|}{ Treated: 671 natives and 334 immigr. } & \multicolumn{4}{|c|}{ Treated: 347 natives and 167 immigr. } \\
\hline \multirow{2}{*}{ Natives } & -0.0565 & -0.0565 & -0.0422 & -0.0438 & -0.0310 & -0.0295 & -0.0325 & -0.0285 \\
\hline & -6.27 & -5.09 & -3.33 & -2.93 & -2.38 & -1.89 & -2.01 & -1.66 \\
\hline \multirow{2}{*}{ Immigrants } & -0.0438 & -0.0185 & -0.0408 & -0.0243 & -0.0277 & -0.0392 & -0.0407 & -0.0277 \\
\hline & -3.11 & -1.02 & -2.12 & -1.17 & -2.01 & -2.49 & -2.15 & -1.29 \\
\hline Quarter 3 & \multicolumn{4}{|c|}{ Treated: 474 natives and 252 immigr. } & \multicolumn{4}{|c|}{ Treated: 239 natives and 126 immigr. } \\
\hline \multirow{2}{*}{ Natives } & -0.0263 & -0.0172 & -0.0306 & - & -0.0245 & -0.0145 & -0.0152 & - \\
\hline & -2.29 & -1.16 & -1.96 & - & -1.63 & -0.80 & -0.77 & - \\
\hline \multirow{2}{*}{ Immigrants } & -0.0176 & 0.0086 & 0.0024 & - & -0.0249 & -0.0370 & 0.0097 & - \\
\hline & -1.08 & 0.39 & 0.11 & - & -1.62 & -2.17 & 0.40 & - \\
\hline Quarter 4 & \multicolumn{4}{|c|}{ Treated: 339 natives and 201 immigr. } & \multicolumn{4}{|c|}{ Treated: 171 natives and 108 immigr. } \\
\hline \multirow{2}{*}{ Natives } & -0.0249 & -0.0138 & - & - & -0.0286 & -0.0277 & - & - \\
\hline & -1.91 & -0.79 & - & - & -1.91 & -1.38 & - & - \\
\hline \multirow{2}{*}{ Immigrants } & 0.0260 & 0.0349 & - & - & -0.0055 & 0.0053 & - & - \\
\hline & 1.21 & 1.42 & - & - & -0.25 & 0.19 & - & - \\
\hline
\end{tabular}

Remarks: Displayed are average treatment effects on the treated and corresponding t-values. Standard errors have been obtained through bootstrapping based on 250 replications. Fields marked by a - indicate that no outcome variable could be observed for the respective month. 
Table 5: Differences in treatment effects between natives and immigrants

\begin{tabular}{|c|c|c|c|c|c|c|c|c|}
\hline \multirow[b]{2}{*}{ Month after program start: } & \multicolumn{4}{|c|}{ Men } & \multicolumn{4}{|c|}{ Women } \\
\hline & 3 & 6 & 9 & 12 & 3 & 6 & 9 & 12 \\
\hline \multicolumn{9}{|l|}{ Quarter 1} \\
\hline$\Delta_{D i f}^{A T T}$ & 0.0331 & 0.0125 & 0.0021 & 0.0041 & -0.0285 & 0.0141 & 0.0401 & 0.0110 \\
\hline p-value & 0.0332 & 0.5143 & 0.9204 & 0.8522 & 0.1958 & 0.5978 & 0.1920 & 0.7369 \\
\hline$\Delta_{\text {residual }}^{A T T}$ & 0.0364 & 0.0210 & 0.0099 & 0.0108 & -0.0109 & 0.0396 & 0.0694 & 0.0596 \\
\hline t-value & 1.77 & 0.89 & 0.42 & 0.43 & -0.46 & 1.17 & 1.75 & 1.65 \\
\hline \multicolumn{9}{|l|}{ Quarter 2} \\
\hline$\Delta_{D i f}^{A T T}$ & 0.0128 & 0.0380 & 0.0015 & 0.0195 & 0.0033 & -0.0097 & -0.0083 & 0.0007 \\
\hline p-value & 0.4331 & 0.0608 & 0.9481 & 0.4319 & 0.8784 & 0.6977 & 0.7647 & 0.9809 \\
\hline$\Delta_{\text {residual }}^{A T T}$ & -0.0022 & 0.0332 & 0.0023 & 0.0305 & 0.0274 & 0.0085 & -0.0083 & 0.0107 \\
\hline t-value & -0.09 & 1.25 & 0.08 & 0.96 & 0.86 & 0.22 & -0.17 & 0.21 \\
\hline \multicolumn{9}{|l|}{ Quarter 3} \\
\hline$\Delta_{D i f}^{A T T}$ & 0.0088 & 0.0258 & 0.0330 & - & -0.0004 & -0.0225 & 0.02489 & - \\
\hline p-value & 0.6622 & 0.3066 & 0.2171 & - & 0.9856 & 0.4180 & 0.4594 & - \\
\hline$\Delta_{\text {residual }}^{A T T}$ & 0.0328 & 0.0635 & 0.0591 & - & -0.0803 & -0.0916 & -0.0145 & - \\
\hline t-value & 1.45 & 2.05 & 1.79 & - & -1.15 & -1.21 & -0.18 & - \\
\hline \multicolumn{9}{|l|}{ Quarter 4} \\
\hline$\Delta_{D i f}^{A T T}$ & 0.0509 & 0.0487 & - & - & 0.0245 & 0.0343 & - & - \\
\hline p-value & 0.0340 & 0.0897 & - & - & 0.3089 & 0.2701 & - & - \\
\hline$\Delta_{\text {residual }}^{A T T}$ & 0.0476 & 0.0359 & - & - & 0.0454 & 0.0661 & - & - \\
\hline t-value & 1.38 & 0.74 & - & - & 1.28 & 1.69 & - & - \\
\hline
\end{tabular}

Remarks: $\Delta_{D i f}^{A T T}$ denotes the mean difference in the ATTs between immigrants and native Germans for the respective program and month after program start. The p-values derive from t-tests on the equality of the ATTs in the group of natives and immigrants. $\Delta_{\text {residual }}^{A T T}$ is based on the matching approach described in section 4.3 and denotes the estimated difference in the ATTs for immigrants and native Germans that is solely due to unobservable differences between the two ethnic groups, or in other words, which is due to the immigrant fixed effect. t-values denote significance of these immigrant fixed effects. Standard errors have been obtained through bootstrapping based on 250 replications. Fields marked by a - indicate that no outcome variable could be observed for the respective month. 


\title{
Additional Appendix To:
}

\section{TEMPORARY EXTRA Jobs FOR IMMIGRANTS: Merging Lane to Employment or Dead-End Road?*}

\author{
Stephan L. Thomsen ${ }^{\dagger}$ \\ University of Magdeburg \& ZEW Mannheim \\ Thomas Walter $\ddagger$ \\ ZEW Mannheim
}

This version: April 16, 2010

Note: In this appendix we provide selected descriptive statistics for our estimation sample. The means of the variables depicted in Tables A.1 to A.4 refer to non-participants (Controls) and participants (Treated) in Temporary Extra Jobs before matching. In Tables A.5 to A.6, treated natives and treated immigrants are compared before matching. All tables are stratified according to the quarter of program start. The p-values derive from t-tests on the equality of means of the displayed variables between the compared groups for the respective quarter.

\footnotetext{
*Financial support from the project Evaluation of the Effects of Basic Social Care for Job Seekers with Migration Background in Germany commissioned by the Federal Ministry of Labor and Social Affairs (BMAS) is gratefully acknowledged. Stephan L. Thomsen thanks the Stifterverband für die Deutsche Wissenschaft (ClaussenSimon-Stiftung) for financial support.

${ }^{\dagger}$ Stephan L. Thomsen is Assistant Professor of Labor Economics at Otto-von-Guericke-University Magdeburg and Research Associate at ZEW, Mannheim. Address: Otto-von-Guericke-University, Department of Economics and Management, PO Box 4120, D-39016 Magdeburg, e-mail: stephan.thomsen@ovgu.de, phone: +49 391 6718431, fax: +493916711700.

${ }^{\ddagger}$ Thomas Walter (Corresponding author) is Research Assistant at the Centre for European Economic Research (ZEW), Mannheim. Address: L7, 1, D-68161 Mannheim, e-mail: walter@zew.de, phone: +49 621 1235363, fax: +49621 1235225 .
} 







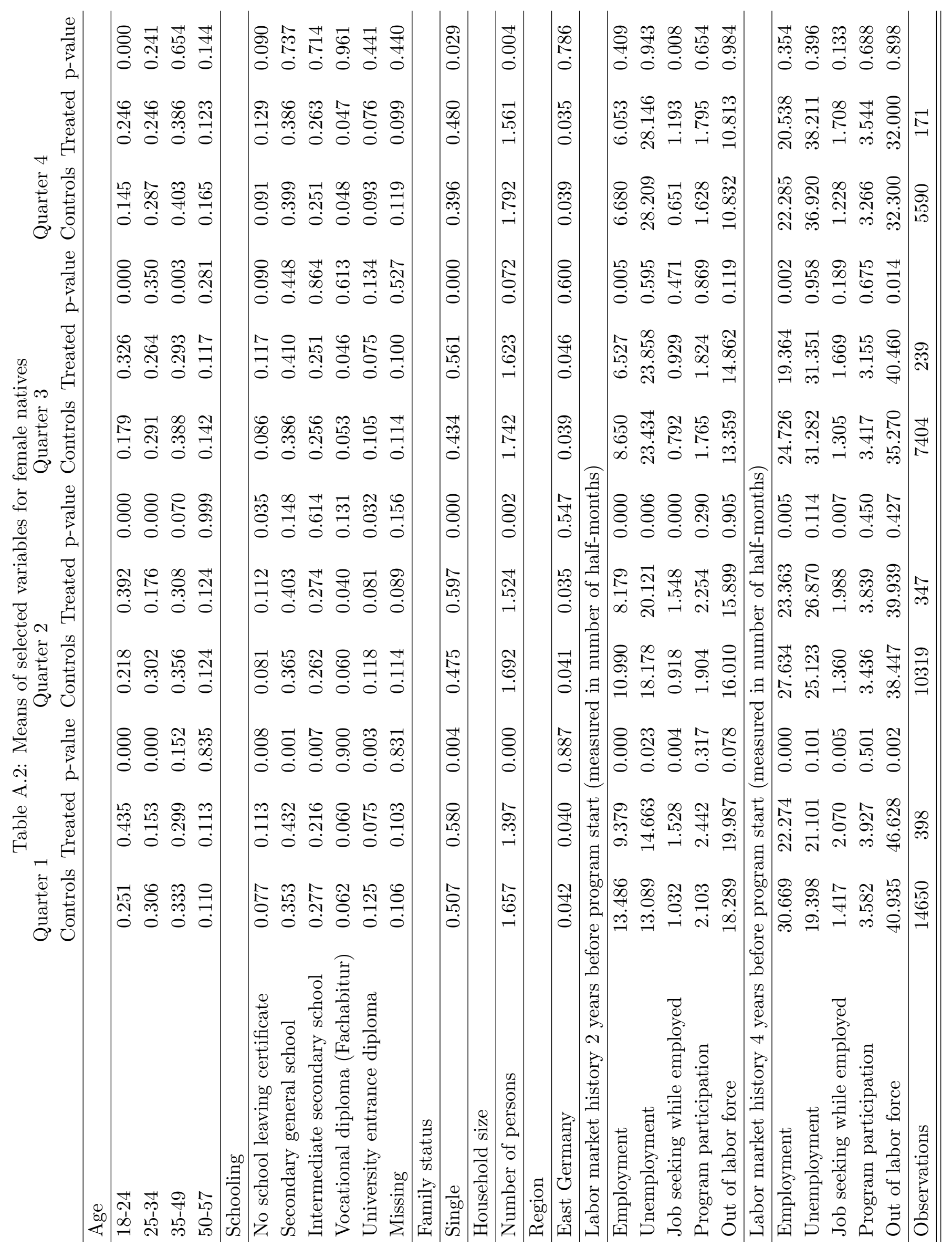




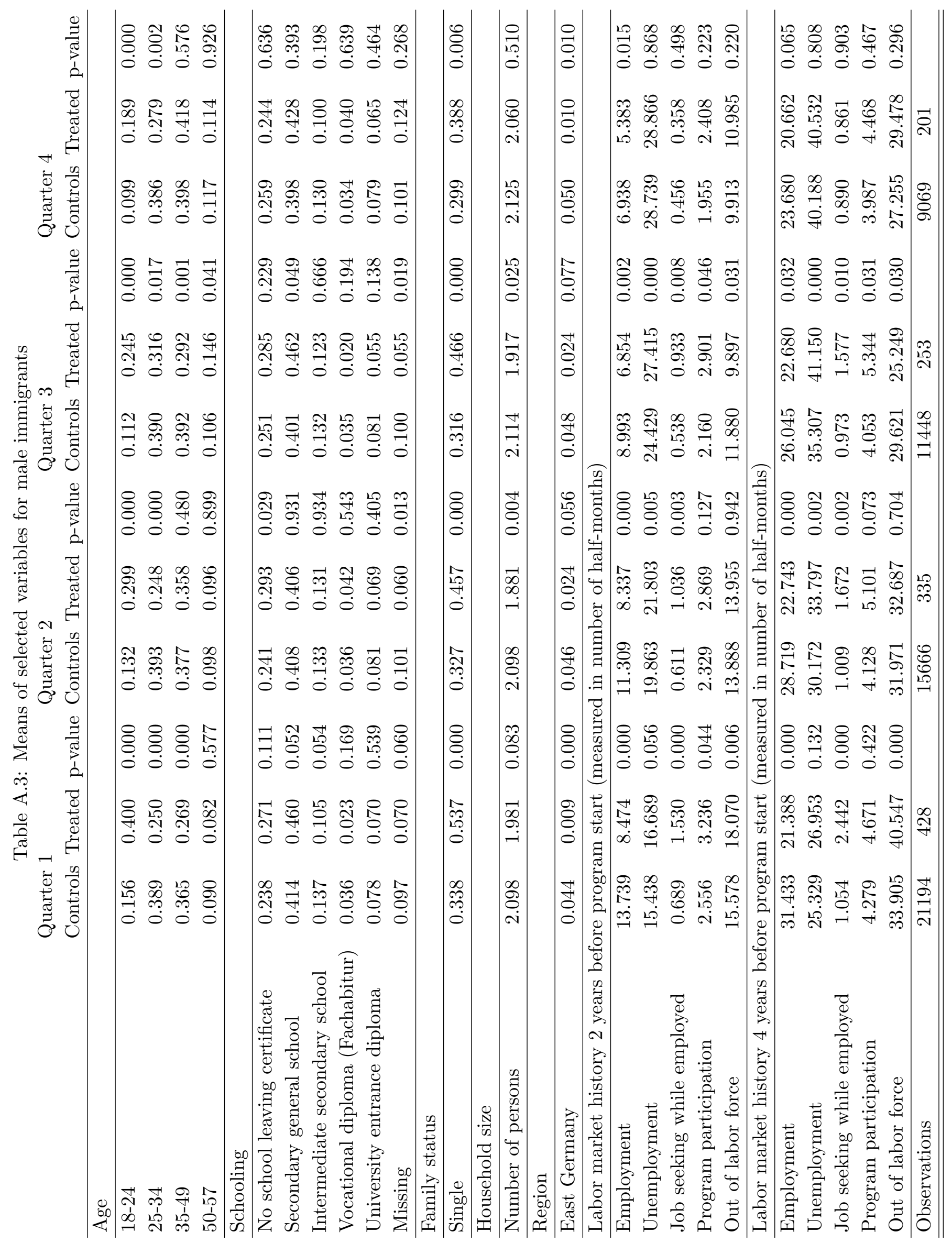




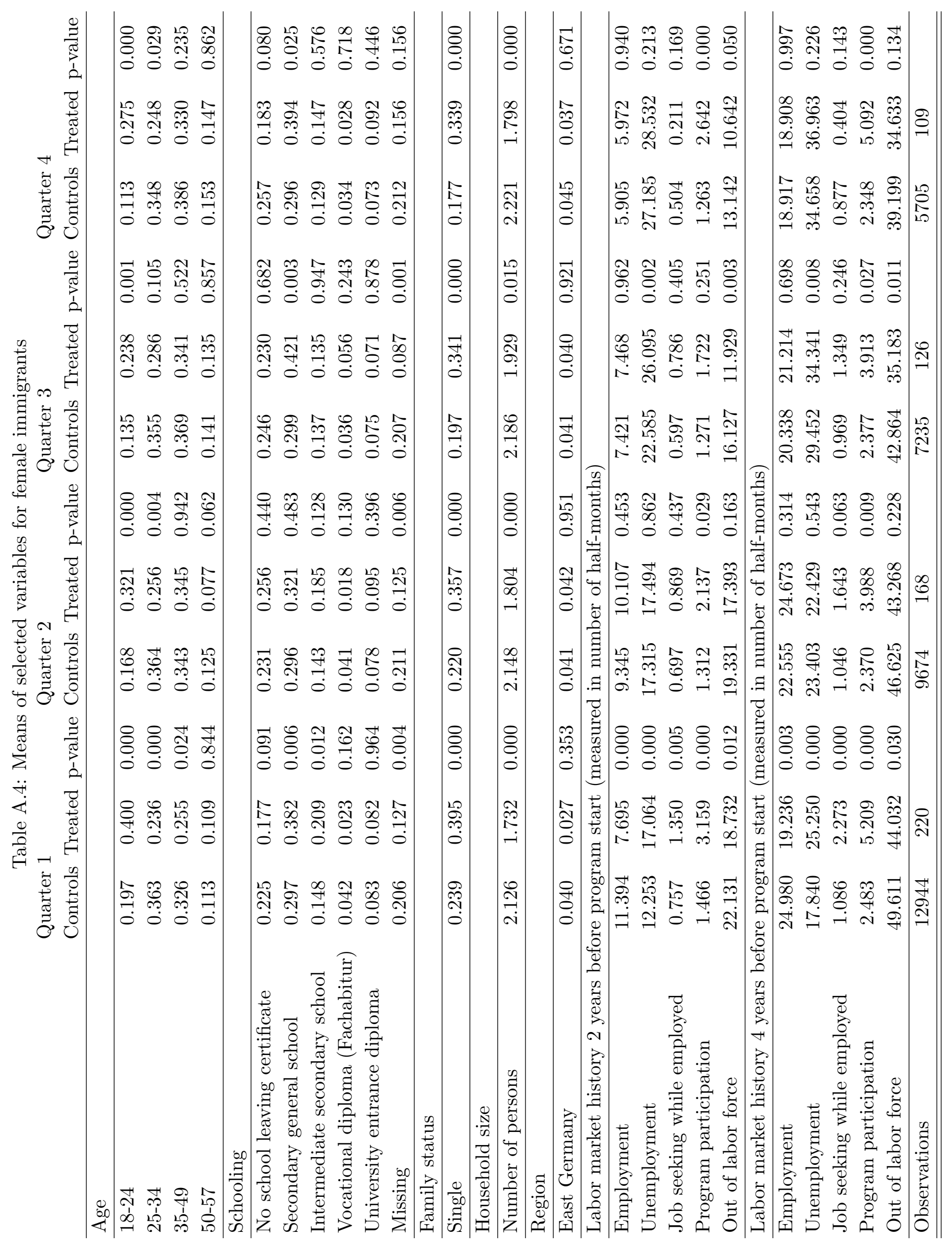




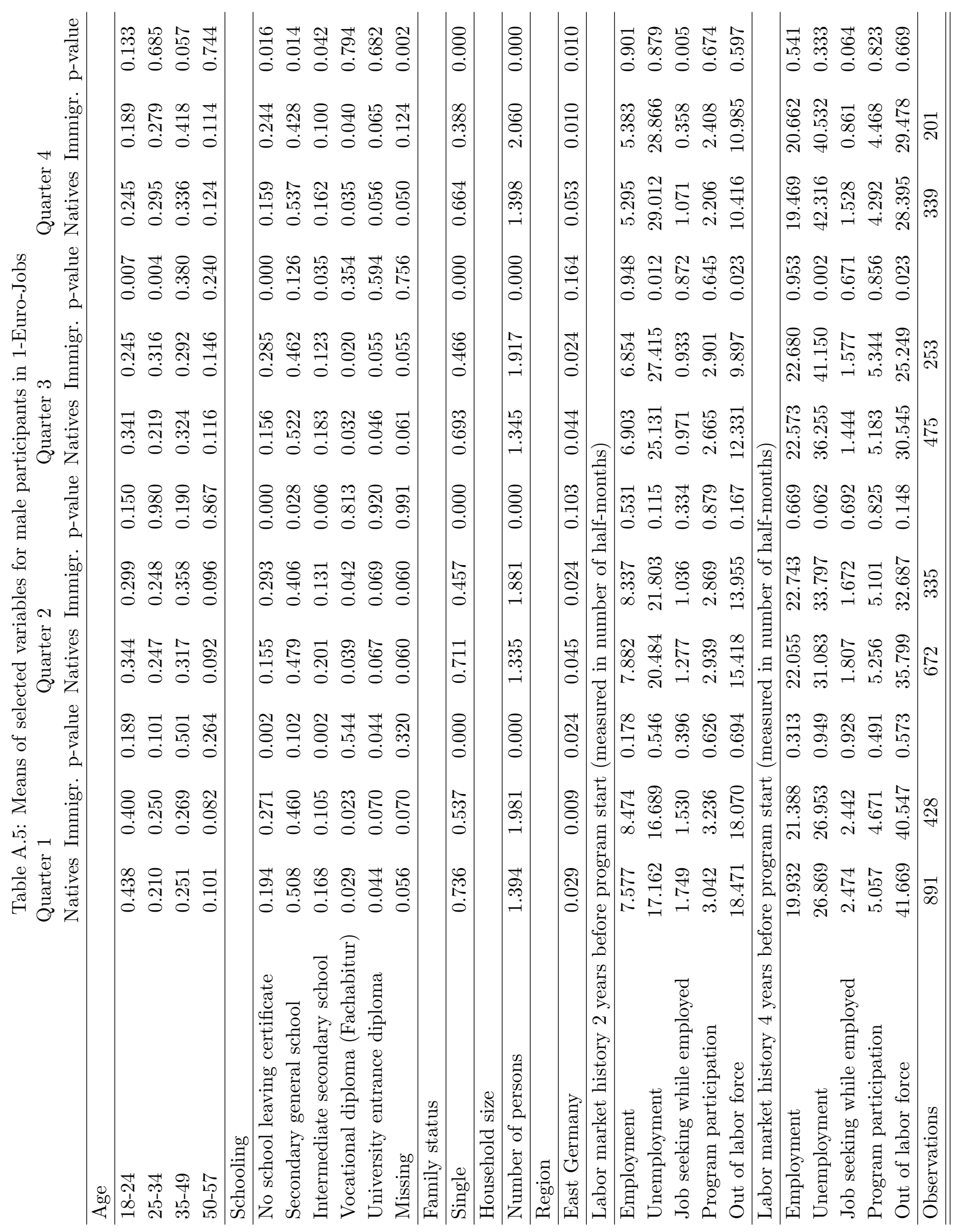






